\title{
Cumhurbaşkanlığı Hükümet Sisteminde Kilit Bir Aktör: Cumhurbaşkanlığı İdari İşler Başkanlığı
}

\author{
A Key Actor in the Presidential Government System: Presidency Directorate of Administratıve Affairs
}

\section{Emre AKCAGÜNDÜZ}

Dr. Arş. Gör., Trakya Üniversitesi, İ̈BF,

Siyaset Bilimi ve Kamu Yönetimi Bölümü,

emreakcagunduz@gmail.com

https://orcid.org/0000-0003-2829-0794
Makale Başvuru Tarihi: 06.07.2021

Makale Kabul Tarihi: 27.08.2021

Makale Türü: Araştırma Makalesi
Anahtar

Kelimeler:

Hükümet

Sistemleri,

Başkanlık Sistemi,

Parlamenter

Sistem,

İdari İşler

Başkanlığl,

Keywords:

Government System,

Presidential System,

Parliamentary

System,

Presidency

Directorate of

Administrative

Affairs,

\section{ÖZET}

16 Nisan 2017'de gerçekleştirilen Anayasa referandumu ile Türkiye Cumhuriyeti Devleti'nin yönetim yapısında önemli değişiklikler meydana gelmiştir. Bu tarihten itibaren parlamenter sistemden başkanlik sistemine doğru bir geçiş yaşanmıştır. Bu geçiş ve akabinde çıkarılan uyum yasalarl ve Cumhurbaşkanlı̆̆l kararnameleri ile merkezi yönetimin başkent teşkilatı büyük oranda değişmiştir. Özellikle yürütme erki tek başlı hale getirilmiştir. Cumhurbaşkani, yürütmenin tek sahibi olmuş, merkezi yönetim de bu eksende şekillendirilmiştir. Bu çerçevede Cumhurbaşkanlı̆̆ı teşkilatında daha önce Türkiye'nin idari yapısında var olmayan farklı birimler ortaya çıkmıştır. Bu birimlerin başında da Cumhurbaşkanlığ İdari Işsler Başkanlı̆̆ gelmektedir. Cumhurbaşkanlığı İdari İsler Başkanlığı, bir önceki sistemde bulunan Cumhurbaşkanlığı Genel Sekreterliği yerine kurulmuştur. Fakat Cumhurbaşkanlı̆̆ İdari İsler Başkanlı̆̆l, Cumhurbaşkanlı̆̆ı Genel Sekreterliği'ne oranla daha fazla görev ve yetkiye sahiptir. Özellikle Cumhurbaşkanlığı İdari Işsler Başkanı, en yüksek dereceli devlet memuru sıfatına sahiptir. Bu çalışmada yapılan literatür taraması sonucunda, hakkında henüz çalışma yapılmadiğı fark edilen Cumhurbaşkanlı̆̆ İdari İ̧̧ler Başkanlığı incelenmiştir. Çalışma üç bölüm olarak tasarlanmıştır. Birinci bölümde, çalışmanın kavramsal çerçevesini oluşturan "hükümet sistemleri" tartışllmıştır. İkinci bölümde, Cumhurbaşkanlı̆̆ hükümet sistemine geçiş süreci açıklanmıştır. Bu bölümde 2007 Anayasa Referandumu ve 2017 Anayasa Referandumu değerlendirilmiştir. Üçüncü bölümde ise Cumhurbaşkanlı̆̆ hükümet sistemi çerçevesinde Cumhurbaşkanlığı teşkilatında nasıl bir değişiklik olduğu ve bu değişiklikte Cumhurbaşkanlı̆̆ İdari İşler Başkanlığının yeri ve önemi tartışılmıştır. Sonuç bölümünde de çalışma sürecinde elde edilen veriler çerçevesinde Cumhurbaşkanlı̆̆ hükümet sistemi ve Cumhurbaşkanlığı İdari Işler Başkanlı̆̆ hakkında genel bir değerlendirme yapılmıştır. 


\section{GIRISS}

Türkiye'de hangi hükümet sisteminin uygulanması gerektiğine dair tartışmalar kadim bir geçmişe sahiptir. Bir ülkede uygulanan hükümet sistemi, uygulandığı ülkenin demokratik yapısından yönetim süreçlerine kadar pek çok alanı etkilemektedir. Bu nedenle, bir ülkede uygulanacak hükümet sisteminin en iyi şekilde belirlenmesi gerekmektedir. Hükümet sistemlerinin niteliğini belirleyen yegâna unsur, erkler (yasama, yürütme ve yarg1) arasındaki ilişkidir. Bu üç erkten "yargıyı” ayrı tutmak gerekmektedir. Yargının, güçler ayrılığı teorisinin ortaya çıkışından beri bağımsız ve tarafsız mahkemelerce gerçekleştirileceği belirtilmektedir. Bu durumda yargı erkinin hükümet sistemlerinin belirlenmesinde "etkisiz eleman" olduğu savunulabilir. Hükümet sistemlerinde esas niteliği belirleyen yasama ve yürütme erklerinin sahip oldukları yetki ve birbirleri arasındaki ilişkidir. Hükümet sistemleri en genel ve basit manada iki temel teori ile açılanmaktadır. Bunlar: "güçler ayrılığı" ve "güçler birlǐ̆ $i$ " teorileridir. Bu teoriler esas olarak yetkilerin yasamada ya da yürütmede toplanması üzerine kurgulanmaktadır.

Kuvvetler ayrılığı teorisi göz önüne alındığında hükümet sistemleri iki ana sisteme ayrılmaktadır. Bunlar: parlamenter sistem ve başkanlık sistemidir. Bu iki sistemin yanında melez bir sistem olarak hem parlamenter sistemin hem de başkanlık sisteminin özelliklerini barındıran yarı başkanlık sistemi de mevcuttur. Kuvvetler birliği teorisinde ise kuvvetlerin yasama organında birleşmesiyle meclis hükümeti sistemi, yürütmede birleşmesiyle monarşi ya da diktatörlük oluşmaktadır (Gözler, 2020:624). Açıkça görüldüğü gibi hükümet sistemleri, bir ülkedeki iktidarın nasıl örgütlendiği ve iktidarın erkler arasında nasıl dağıldığını belirlemektedir (Kılıç, 2016:448-451).

Türkiye'deki anayasal gelişim süreci incelendiğinde farklı dönemlerde farklı hükümet sistemlerinin uygulandığ1 görülmektedir. Türkiye'deki anayasal gelişmeler Osmanlı Devleti'nin son döneminden itibaren başlamaktadır. 1876 yılında yürürlüğe giren Kanunuesasî’nin ilk hali ve sonradan yapılan değişikliklerle farklı hükümet sistemleri ortaya çıkmıştır. Kanunuesasînin ilk halinde her ne kadar erklerden (yasama, yürütme ve yargıdan) bahsedilse de yürütme erkinin (yani padişahın) yetkileri oldukça fazladır. Kanunuesasînin ilk hali "Anayasal Mutlakıyet" olarak tanımlanabilir. Kanunuesasî’nin ilk haline getirilen eleştiriler ve sonrasında yaşanan gelişmeler (1. ve 2. Meşrutiyet ile 1909 değişiklikleri) ile padişahın yetkileri azaltılmıştır. Bu gelişmelerden sonra meşruti monarşiden parlamenter monarşiye geçilmiştir (Keskinsoy ve Kayan, 2018:81). Kısaca 1876 Kanunuesasî ile Mutlak Monarşi’den Anayasal Monarşi sistemine geçilmiştir.

1921 Anayasası ile yasama, yürütme ve yargı erkleri Büyük Millet Meclisi’nde toplanmıştır. Bu şekilde güçler birliği ilkesine dayalı olan "Meclis Hükümeti Sistemi" ortaya çıkmıştır. 1921 Anayasası ile ortaya çıkan hükümet sisteminde yarg1 Büyük Millet Meclisi'nin bünyesinde kurulan “İstiklal Mahkemeleri” eliyle yürütülmüştür. Yürütme yetkisi de (milletvekillerinden oluşan) Bakanlar Kurulu'na verilmiştir. Büyük Millet Meclisi'nin Başkanı aynı zamanda hükümetin de başkanıdır. 1923 yılında yapılan değişiklikle Cumhurbaşkanlığı ve Başbakanlık makamları oluşturulmuştur. Cumhurbaşkanı, milletvekillerince yine milletvekilleri arasından; Başbakan da Cumhurbaşkanı tarafından milletvekilleri arasından seçilecektir. Bakanlar da Başbakan tarafından milletvekilleri arasından seçilecektir. Dikkat edilirse yürütme organı, 1923 değişiklikleri ile yavaş yavaş ayrı bir şekilde oluşmaya başlamıştır. 1921 Anayasası'nda 1923 yılında yapılan değişiklikle hükümet sistemi yavaş yavaş güçler birliğine dayanan meclis hükümeti sisteminden güçler ayrılığına dayanan parlamenter sisteme doğru kaymıştır (Demir, 2000:61-62).

1924 Anayasası, yapı olarak 1921 Anayasası'nın getirmiş olduğu güçler birliğine bağlı "Meclis Hükümeti” sistemini devam ettirmiştir. 1924 Anayasası'nın üçüncü ve dördüncü maddelerinde yasama ve yürütme yetkisinin açikça Türkiye Büyük Millet Meclisi’nde (TBMM) de olduğu belirtilmektedir. Yasama direkt mecliste, yürütme ise yasamanın seçtiği Cumhurbaşkanı ve Cumhurbaşkanın seçtiği Bakanlar Kurulu'ndadır. 1924 Anayasası'nda her ne kadar yargının bağımsız mahkemelerde (8. madde) olduğu belirtilse de yarg1 erki bağımsız değil TBMM'nin güdümü altındadır (Mumcu, 1986:392-396). Kısaca 1924 Anayasası'nda belirtilen hükümet sisteminin 1921 Anayasası'nda belirtilen hükümet sisteminden belirgin bir fark1 yoktur.

1961 Anayasası ile Türkiye'de "güçler ayrılığı ilkesine" dayalı bir sistem kurulmuştur. 1961 Anayasası ile erkler birbirinden kesin olarak ayrılmıştır (Tunç, 2020:672). 1961 Anayasası ile yumuşak güçler ayrıllı̆gna dayalı parlamenter sistem kabul edilmiştir. 1961 Anayasası'nın 4-5-6 ve 7. maddelerinde güçler ayrilığı ilkesi açıça belirtilmiştir. Dördüncü maddede; "Millet, egemenliğini, Anayasa'nın koyduğu esaslara göre, yetkili organlar eliyle kullanır", ifadesi ile erklerin ayrılığı ilk defa açıkça belirtilmiştir. 1961 Anayasası ile meclis üstünlüğü ilkesi yerine Anayasa'nın üstünlüğü ilkesi kabul edilmiştir (Demir, 2000:64). Sonuç olarak 1961 Anayasası ile artık diğer Anayasa'lardan farklı olarak güçler ayrılığına dayalı parlamenter sisteme geçilmiştir. 
Halen uygulamada bulunan 1982 Anayasası'na bakıldığında, hükümet sisteminin dönemden döneme yapılan Anayasa değişiklikleri ile farklılaştığı görülmektedir. 1982 Anayasası'nın öngördüğü hükümet sistemi farklı dönemlerde yapılan değişikliklerle belirlenmiştir. Bu nedenle 2007 ve 2017 yıllarında yapılan değişiklikler önem arz etmektedir. Kısaca 1982 Anayasası ile belirlenen hükümet sistemi üç döneme ayrılabilir. Bunlar: 1982-2007 arası dönem, 2007-2017 arası dönem ve 2017 sonrası dönem. 1982 Anayasası'nın ilk halinde kuvvetler ayrılığ 1 ilkesi benimsenmiştir. Özellikle yasama ve yürütme erklerinin birbirinden bağımsız olması gerektiği vurgulanmıştır. Fakat bu ayrılık sert anlamda değil işbirliğine dayalı bir ayrılıktır. 1982 Anayasası'nın 2007 yılına kadarki döneminde, klasik parlamenter sistemden bazı noktalarda farklılaşmış̧ır. Yasama-yürütme ilişkilerinde özellikle yürütmenin yetkileri klasik parlamenter sisteme nazaran daha fazladır. Yürütmede sorumlu ve sorumsuz kanat olmak üzere ikili bir yapı vardır. Sorumlu kanat başbakan ve bakanlar kurulu, sorumsuz kanat ise Cumhurbaşkanı'dır (Çekiç, 2016:458).

2007 yılında yapılan Anayasa değişikliği ile Cumhurbaşkanı artık TBMM tarafından değil, halk tarafından seçilecektir. Bu değişiklikle birlikte artık Cumhurbaşkanı klasik parlamenter sistemde olduğu gibi meşruiyetini TBMM'den değil, halktan almaktadır. Bu durumda Cumhurbaşkanı, arkasında halkın desteğini hissetmektedir. Bu nedenle 2007 Anayasa değişikliği sonrası Cumhurbaşkanı yetkilerini daha rahat kullanabilmektedir. 2007 değişikliği ile parlamenter sistemden yarı başkanlık sisteme daha yakın melez bir sisteme geçildiği savunulabilir. Son olarak 2017 yılında yapılan geniş kapsamlı Anayasa değişikliği ile Türkiye "Cumhurbaşkanliğı Hükümet Sistemine" geçmiştir.

Çalışma üç bölüm olarak tasarlanmıştır. Birinci bölümde, çalışmanın kavramsal haritası ortaya konulmuştur. Bu bölümde çalışmanın ana teması olan hükümet sistemleri ve çeşitleri tartışılmıştır. İkinci bölümde, Cumhurbaşkanlığı hükümet sistemine geçiş süreci, 2007 ve 2017 Anayasa değişliği referandumları çerçevesinde tartışılmıştır. Bu bölümde, yapılan referandumlar sonrasında Anayasa'da hangi değişikliklerin olduğu ve bu değişiklikler sonucunda hükümet sisteminin nasıl etkilendiği açıklanmıştır. Üçüncü bölümde (4. ana başlıkta) Cumhurbaşkanlığı hükümet sistemi ile birlikte Cumhurbaşkanlığ İşler Başkanlığı incelenmiştir.

Çalışmanın temel amacı; Cumhurbaşkanlığı hükümet sisteminde önemli bir rolü olan İdari İşler Başkanlığı ile ilgili derinlemesine bir analiz yapılıp bu kurumun literatüre kazandırılmasıdır. Bu nedenle çalışmada nitel araştırma tekniğinin bir alt dalı olan "nitel durum analizi yöntemi” kullanılmıştır. Nitel araştırma tekniği "Gözlem, görüşme, doküman analizi (ses, içerik vb.) nitel veri yöntemlerinin kullanıldığg, algıların ve olayların rasyonel veriler ile doğal ortamda ve gerçekçi veriler ile bütüncül bir biçimde ortaya konmasına yönelik araştırma sürecidir." (Yıldırım ve Şimşek, 2006: 39).

Nitel durum analizi, "belirli bir vakanın, çeşitli verilerle neden-sonuç ilişkisi içeresinde incelenerek, önceden belirlenen araştırma sorularına yanıt bulmayı amaçlayan" nitel araştırma yöntemidir (Subaşı ve Okumuş, 2017). Çalışmada Cumhurbaşkanlığı hükümet sistemi ve bu sistem ile oluşturulan İdari İşler Başkanlığ çeşitli dokümanlar (mevzuat hükümleri, Cumhurbaşkanlığı kararnameleri, konu ile ilgili yazılmış makale, kitap, akademik tezler ) incelenerek hazırlanmıştır. Konu ile ilgili araştırma yapılırken Google Scholar, online kütüphaneler, Yüksek Öğretim Kurumu Tez Merkezi Kataloğu ve online makale veri tabanlarından yararlanılmıştır. Araştırma sonucunda, dokümanların incelenmesi ile elde edilen bilgiler, sistematik bir şekilde analiz edilip yorumlanmıştır.

\section{KAVRAMSAL ÇERÇEVE: HÜKÜMET SİSTEMLERİ ÜZERINNE}

Hükümet sistemlerinin anlamı ve mantığını anlayabilmek için bu kavramın ortaya çıkmasını sağlayan temel teorilere bakılması gerekmektedir. Literatürdeki hükümet sistemi tanımları (Gözler, 2020:623; Özdemir, 2018:11-12; Keskinsoy ve Kaya, 2018:69-70; Korkmaz, 2016:44; Kılıç, 2016:447; Hekimoğlu, 2009:5) kuvvetler ayrıllğı ve kuvvetler birliği teorileri üzerinden yapılmıştır. Bu nedenle hükümet sistemleri incelenirken her iki teoriden de bahsedilmesi gerekmektedir.

Kuvvetler ayrılığı teorisinin kökeni Aristo’ya kadar götürülmektedir. Fakat kuvvetler ayrıllı̆ı teorisini, sistemli olarak (günümüzdeki yaygın anlamıyla) 17. yüzyılda John Locke ve 18. yüzyılda Montesquieu incelemiştir. 17. ve 18. yüzyılda bu iki düşünür tarafından güçler ayrımı teorisinin incelenmesi ve savunulması tesadüfî değildir. Zira bu iki düşünürün de yaşadıkları dönemde egemen yönetim biçimi mutlak monarşidir. $\mathrm{Bu}$ yönetim biçiminde yasama, yürütme ve yargı erkleri bir kişide toplanmıştır. Bu yönetim biçiminin tekrar oluşmasının engellenmesi için yasama, yürütme ve yargı erklerinin farklı kurumlarda olması amaçlanmıştır. Bu şekilde 
güçler ayrıllğı teorisi sistemleştirilmiştir. Locke, mutlak monarşiyi oluşturan üç erki yasama, yürütme ve federatif güç olarak tanımlamıştır (Tunçay, 1969:178-179; Çam, 2005:378-379, Karaman, 2020:23).

Montesquieu ise güçler ayrıllı̆ı teorisini yasama, yürütme ve yargı olarak sistemleştirmiştir. Montesquieu'nun bu konuya kafa yormasının çeşitli nedenleri vardır. Montesquieu'nun öncelikli nedeni, Fransız Kralı XIV. Louis'in mutlak monarşik yönetimidir. Bu yönetim sisteminden kaçarak farklı ülkelerden bulunan Montesquieu, özellikle İngiltere'de bulunduğu iki yıl boyunca buradaki sistemden ve Locke'nin görüşlerinden etkilenmiştir. Montesquieu, İngiltere'deki "hâkimlerin bağımsızlı̆̆l ve parlamentonun gücünden" etkilenmiştir (Akyılmaz, 1995:49). Montesquieu, mutlak monarşinin engellenmesi için güçler ayrılığı ilkesinin gerekliliği ile ilgili şu görüşü paylaşmaktadır (Montesquieu'dan aktaran Akyılmaz, 1995:53); "Ezeli bir tecrübe ile sabittir ki kuvvet sahibi herkes bunu kötüye kullanmaya meyleder ve kuvvetine sinır buluncaya kadar gider. Fazilet dahi sinırlandırılmaya muhtaçtır. Kuvvet kötüye kullanılmamak için o surette düzenlenmelidir ki kuvvet kuvveti durdursun". Bu alıntıda da açıkça görüldüğü gibi Montesquieu güçler ayrılığı teorisini bir nevi "denge denet düzeneğine" benzetmiştir. Bu erklerin farklı kurumlarda olması yaşanacak yönetim suistimallerinin (mutlak monarşi gibi) önüne geçecektir.

Kuvvetler ayrılı̆̆ 1 teorisi zamanla gelişerek farklı ülkelerde, farklı şekillerde uygulanmaya başlamıştır. Güçler ayrılığı teorisinde belirtilen yasama, yürütme ve yarg1 erklerinin yönetsel sistemdeki yeri, ağırlıkları ve işlevlerine göre farklı hükümet sistemleri (başkanlık ve yarı başkanlık) ortaya çıkmıştır.

Şekil 1. Kuvvetler Birliği ve Kuvvetler Ayrılığı Prensibine Göre Hükümet Şekilleri

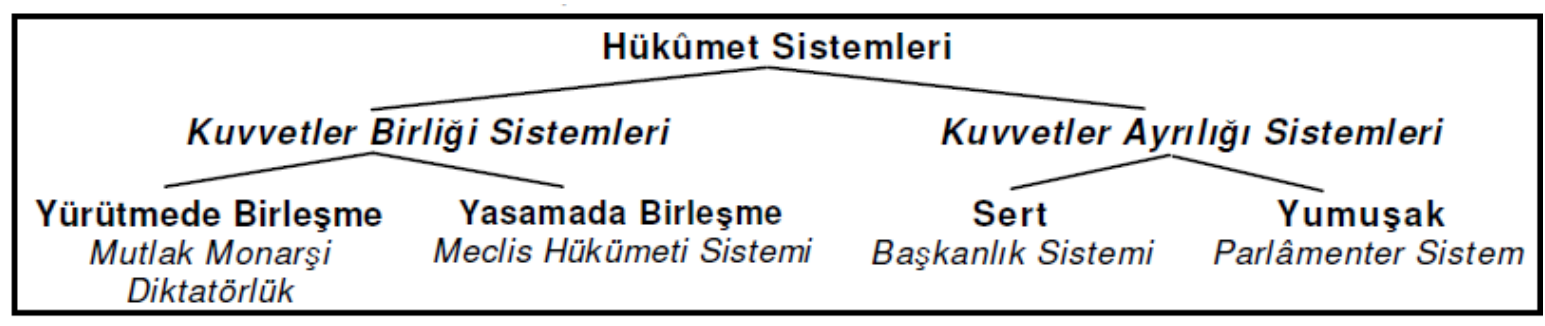

Kaynak: Gözler, 2020:624.

Kuvvetler birliği sistemleri ise yasama, yürütme ve yarg1 erklerinin bir kişi ya da bir kurumda toplanması ile oluşmaktadır. Eğer kuvvetler bir mecliste birleşmişse ortaya "meclis hükümeti" sistemi çıkmaktadır. Türk Anayasa tarihinde 1921 Anayasası ile oluşan sistem, meclis hükümeti sistemine örnek olarak verilebilir. Yine günümüzde İsviçre'de uygulanan sistem, meclis hükümeti sistemine örnek verilebilir. Bu sistemin bazı temel özellikleri mevcuttur. Öncelikle meclis (yani parlamento) yürütme erkine sahiptir ve sistemin ana unsurudur. Hükümet üyeleri doğrudan parlamento tarafından seçilir ve parlamentonun memuru konumundadırlar. $\mathrm{Bu}$ sistemde tek meclis öngörülür ve devlet başkanı yoktur (Sezginer, 2010:31-32).

Erklerin bir kişide toplanması ile diktatörlük ya da mutlak monarşi ortaya çıkmaktadır. Bu iki kavram genellikle birbirine benzemekte ve karıştırılmaktadır. Mutlak monarşi, soy bağıyla yani babadan oğula, bir aile mirası olarak yönetimin bir kişiye bir diğer kişiye geçmesidir. Bu sistemde yasama ve yürütme mutlak monarka yani krala aittir. Yine yargı da krala bağlı olarak çalışır. Diktatörlük ise çeşitli olaylarla örneğin; darbe, toplumsal kriz vb. durumlarda bir kişinin iktidara gelip yasama, yürütme ve yarg1 erklerini gasp etmesiyle oluşur. İktidara gelen diktatör kısa sürede başta Anayasa ve diğer mevzuatları kendi lehine değiştirerek yönetime tamamen egemen olmaya çalışır. Böylece diktatör "sosyal ya da politik" herhangi bir güç tarafindan sinırlanmayacak hale gelerek mutlak bir yönetim sağlar. Genellikle bu yönetim şekli diktatörün adı ile anılır ve askeri rejimlerin yönetimi ele geçirmesi ile s1k s1k görülür. Diktatörlük kişi ya da grup diktatörlüğü şeklinde görülebilir (Kışlalı, 1991:194-199; Gözler, 1999:52-54; Burhan, 2020:112).

Kuvvetler ayrılığı teorisine göre ise hükümet sistemleri, parlamenter sistem ve başkanlık sistemi olmak üzere ikiye ayrılmaktadır. Parlamenter sistemde (adından da anlaşılacağı gibi) egemen güç parlamentodur. Bu sistemde yasama parlamentodadır, ayrıca yürütme de parlamentonun içinden çıkmaktadır. Yürütmenin başı olan başbakan, parlamento mensubudur. Bakanlar da parlamento mensubudur. Bakanların hem parlamento mensubu olması hem de yürütmede olmaları yasama ve yürütme ilişkilerinde "yumuşak bir geçiş" sağlamaktadır. Bu nedenle parlamenter sisteme "yumuşak güçler ayrılı̆̆g" da denmektedir. Yani bu sistemde kuvvetlerin ayrillı̆g 1 görece daha zayıftır (Yayla, 2014:70-71). Parlamenter sistemin bazı temel özellikleri vardır. Bu özellikler, sistemin daha rahat anlaşılmasını sağlamaktadır. Bu özellikler şunlardır (Caner, 2013:185-189); 
- Yürütme yani hükümet yasama organı içinden çıkmaktadır.

- Hükümet, parlamentoya karşı sorumludur.

- Yürütme sorumlu kanat (başbakan) ve sorumsuz kanat (devlet başkanı) olmak üzere iki bir yapı sergilemektedir.

- Parlamento çeşitli yollarla hükümeti denetlemekte, hatta fesih edebilmektedir.

Kuvvetler ayrılığı teorisinin bir diğer çeşidi de başkanlık sistemidir. Başkanlık sistemi, kuvvetlerin yani erklerin sert ayrıllğına dayanan bir sistemdir. Yasama ve yürütme birbirlerinin işlerine karışmaz. Ne yasama yürütmeyi ne de yürütme yasamayı feshedemez. Yürütmede görev alan bir kişi yasamada kesinlikle görev alamaz. Bu sistemde yürütme organı halk tarafından seçilmektedir. Yürütme tekli bir yapıdadır yani devlet başkanı ve hükümet başkanı ayrımı olmayan bir sistemdir. Başkan, meşruiyetini parlamentodan değil, halktan alır. Yürütmede, başkana yardımcı olan kabine, başkan tarafindan oluşturulur. Başkanlık sisteminde yürütme tamamen başkanda olduğu için başkanın pek çok konuda bilgisinin olması gerekir. Bu durumu, başkan, kendi seçtiği ve atadığı bakanlar aracılıyla çözer. Başkanın parlamentoya karşı siyasi sorumluluğu yoktur. Fakat göreviyle ilgili suçlardan dolay1 cezai sorumluluğu mevcuttur (Ergil, 2015:22-24; Akınc1, 2017:4-5; Ertaş, 2018:157).

Son olarak parlamenter sistem ve başkanlık sisteminin özelliklerini kendi içerisinde barındıran ve "melez sistem" olarak adlandırılan yarı başkanlık sistemine bakılması gerekmektedir. Pratikte Fransa'da uygulama bulan bu sistemde, başkan, doğrudan halk tarafından seçilmektedir. Fakat yürütme iki başlıdır. Hem devlet başkanı hem de parlamentodan çıkan bir başbakan mevcuttur. Yani hükümet parlamentodan çıkmaktadır. Fakat burada önemli olan devlet başkanın halk tarafindan seçilmesi ve meşruiyetinin sağlam olmasıdır. Ayrıca bu sistemde devlet başkanının geniş yetkileri de mevcuttur. Bu sistemde genellikle seçimlerde en çok oyu alan partinin başkanı, devlet başkanı tarafından başbakan olarak atanır. Fakat başbakanı devlet başkanı değil, parlamento görevden düşürebilir. $\mathrm{Bu}$ sistemde hükümet hem parlamentoya, hem de devlet başkanına karşı sorumludur (Akınc1, 2017:5-6; Yayla, 2014:72-73).

\section{YENI SISTEME GEÇIŞ SÜRECİ: 2007 VE 2017 ANAYASA DEĞiş̧iKLIĞİ REFERANDUMLARI}

1982 Anayasası, yürürlüğe girdiği tarihten itibaren hem çeşitli eleştirilere neden olmuş hem de pek çok maddesi değiştirilmiştir. Özellikle 2002 genel seçimlerinden sonra Adalet ve Kalkınma Partisi'nin iktidara gelmesi ile 2021 yılına kadar 1982 Anayasası'nın 134 hükmü değiştirilmiştir (www.milliyet.com.tr, 2021). Günümüzde de halen yeni bir Anayasa yapılması için başta siyasi partiler ve sivil toplum kuruluşları olmak üzere pek çok kurum ve kuruluş çaba göstermektedir. 1982 Anayasası'nda yapılan değişiklikler içerisinde 2007 ile 2017 ayrı bir yere ve öneme sahiptir. Bu iki Anayasa değişikliği ile parlamenter sistem terk edilmiş, yarı başkanlık sisteminden başkanlık sistemine doğru bir geçiş yaşanmıştır.

2007 Anayasa değişikliği referandumu, parlamenter sistemden başkanlık sistemine geçişte bir "ara dönem" yarattı̆ğ savunulabilir. 2007 yılında yapılan referandum sonucunda 1982 Anayasası'nın 77-79-96-101 ve 102. maddeleri değiştirilmiştir. Kısaca bu değişikliklerin içeriği şu şekildedir (Yavuz, 2008:1176):

- 77. maddede yapılan değişiklikle milletvekili seçimleri dört yıldan beş yıla çıkarılmıştır. Bu süre Cumhurbaşkanın görev süresi ile aynıdır. Bu değişiklik ile görev süreleri hakkında bir 'uyumlaştırma' yapılmıştır. Böylece hem Cumhurbaşkanı için hem de milletvekilliği için ayrı ayrı seçim yapılmasının önüne geçilmiştir.

- 79. madde de yapılan değişiklikle bu maddeye; "seçim tutanakları" ibaresinden sonra gelmek üzere "ve Cumhurbaşkanlığı seçimi tutanakları" ibaresi; son fikrasında geçen "halkoyuna sunulması" ibaresinden sonra gelmek üzere "Cumhurbaşkanının halk tarafindan seçilmesi" ibaresi eklenmiştir (Yavuz, 2008:1176). Bu değişiklik de bir "uyumlaştırma" olarak okunabilir. Bu değişiklikle Yüksek Seçim Kurulunun (YSK) görev alanı ile ilgili yaşanabilecek sorunlar ortadan kaldırılmıştır. Yine bu değişiklik ile 101. ve 102. maddelerde yapılan değişiklikler arasında bir uyumlaştırma yapılmıştır.

- 96. madde de “TBMM'nin yapacă̆ seçimler ve diğer bütün işlerinde üye tamsayısının en az 1/3 ile toplanacağl, TBMM, (Anayasada başkaca bir hüküm yoksa) toplantıya katılanların salt çoğunluğu ile karar vereceğini fakat karar yeter sayısı hiçbir şekilde üye tamsayısının 1/4’ünün bir fazlasından az 
olamayacağl" hükmü getirilmiştir. Bu maddedeki değişikliğin esas nedeni, kamuoyunda da "367 Krizi" olarak anılan olaydır. Bu değiş̧iklik ile Cumhurbaşkanı seçiminde yaşanabilecek sayılardan ve ifadelerden kaynaklı karmaşa giderilmiş. Cumhurbaşkanı seçimi süreci açık ve net bir şekilde belirlenmiştir.

- 101. madde de Cumhurbaşkanı’nın görev süresinin beş yıl olduğu, bir kişinin en çok iki kez Cumhurbaşkanı seçielebileceği, Cumurbaşkanı seçilen kişinin partisi ve varsa TBMM ile olan ilişkisinin sona ereceği belirtilmiştir. Yine bu maddede açıkça Cumhurbaşkanı'nın halk tarafından seçileceği belirtilmiştir. $\mathrm{Bu}$ durumda Cumhurbaşkanı artık gücünü (meşruiyetini) halktan alacaktır. Bu durum Cumhurbaşkanı'nın konumunu farklı bir yere taşımıştır. Bu değişiklikle artık başkanlık sistemine geçişte ara bir rejim olan yarı başkanlık sistemine geçildiği savunulabilir. Yarı başkanlık sisteminin en önemli özelliği meşruiyetini halktan alan bir Cumhurbaşkanı'nın olmasıdır. Bu maddede son olarak Cumhurbaşkanlığına aday olmak için en az 20 milletvekili ya da en son yapılan TBMM üye seçimlerinde geçerli oylar toplamı birlikte hesaplandığında \%10'u geçen siyasi partilerin ortak bir aday gösterebileceği düzenlenmiştir. Bu değişiklikle de Cumhurbaşkanlığına aday göstermede bir uzlaşı durumu yaratılmaya çalışıldığı savunulabilir.

- 102. madde de ise Cumhurbaşkanı seçimi süreci (halk oylaması) detaylı bir şekilde açıklanmıştır. Madde de, Cumhurbaşkanı'nın görev süresinin dolmasından önce ya da makamın çeşitli nedenlerle boşalması durumunda seçimlerin nasıl ve kaç günde yapılacağı belirtilmiştir. Yine bu maddede Cumhurbaşkanı göreve başlayıncaya kadar görev süresi dolan Cumhurbaşkanı'nın göreve devam edeceği ve Cumhurbaşkanlığı seçimine ilişkin düzenlemelerin kanunla yapılacağı belirtilmiştir.

Sonuç olarak 2007 değişikliği ile Türkiye'de özellikle Cumhurbaşkanı'nın halk tarafından seçilmesi usulünün kabulü ile parlamenter sistem ile başkanlık sistemi arasında melez bir sistem olan yarı başkanlık sistemine geçildiği savunulabilir.

Türkiye'de başkanlık sistemine tam anlamı ile geçiş 16 Nisan 2017 Anayasa değişikliği referandumu ile olmuştur. 2007 yılında temelleri atılan başkanlık sistemi, 2017 yılında yapılan kapsamlı Anayasa değişikliği ile hayata geçirilmiştir. 16 Nisan 2017 yapılan referandum da 1982 Anayasası'nın 18 maddesinde yapılacak olan değişiklikler oylanmıştır. Yapılan oylamada \%51,18 evet; \%48,82 hayır oyu çıkmış ve değişiklikler kabul edilmiştir (YSK, 2017). Yapılan değişikliklerle ${ }^{1}$ Cumhurbaşkanlığı makamı, başkanlık sistemi esas alınarak yeniden düzenlenmiştir. Öncelikle Anayasa'nın 77. maddesinde TBMM milletvekili seçimleri ile Cumhurbaşkanlığı makamı seçimlerinin aynı gün ve beş yılda bir yapılacağ belirtilmiştir. Esas önemli değişiklikler Anayasa'nın 104, 105, 106, 116 ve 161. maddeleri ile gerçekleşmiştir. 104. madde ile yapılan değişikliklerin bazılarılar şu şekildedir;

- Cumhurbaşkanı artık yürütmenin tek sahibi ve başıdır. Bu nedenle Cumhurbaşkanı, devletin bütün organlarının düzenli ve koordineli biçimde çalışmasını sağlamakla yükümlüdür.

- Cumhurbaşkanı'nın TBMM ile bir üyelik bağı yoktur. Yani Cumhurbaşkanı seçilen kişinin TBMM üyeliği düşmektedir. Fakat Cumhurbaşkanı eğer ihtiyaç olur ve gerekli görürüse, yasama yılının ilk günü, TBMM'de açılış konuşmasını yapabilir.

- Cumhurbaşkanı, bakanları ve yardımcılarını atar, yine bu kişilerin görevlerine son verebilir.

- Cumhurbaşkanı, üst düzey (kademe) kamu personelinin atamaları, görevlerine son verilmeleri ile ilgili tek yetkilidir. Yine bu personelin nasıl atanacağına dair gerekli düzünlemler, Cumhurbaşkanlığı kararnamesiyle yapılmaktadır.

- Cumhurbaşkanı, yabancı devletlere temsilciler gönderebilir ve aynı şekilde farklı ülkelerden gönderilen yabancı devlet temsilcilerini kabul edebilir.

- Cumhurbaşkanı, Anayasa değişiklikleriyle ilgili yasaları istediği takdirde (eğer gerekli görürüse) halkoyuna sunabilir.

- Cumhurbaşkanı, milli güvenlik ile ilgili konularda ve politikalarda gerekli tedbirleri alıp gerektiğinde bu karar ve politikaları belirleyebilir. Cumhurbaşkanı, yürütme yetkisine ilişkin idarenin bir düzenleyici işlemi olarak Cumhurbaşkanlığı kararnamesi çıkarabilir.

117 Nisan 2017 Anayasa değişikliği referandumunda pek çok konu düzenlenmiştir. Bu bölümde sadece yürütme fonksiyonu (Cumhurbaşkanı) hakkında yapılan değişiklikler incelenmiştir. Düzenlenen diğer maddeler ve içerikleri için bkz: https://www.resmigazete.gov.tr/eskiler/2017/02/20170211-1.htm. 
105. maddede yapılan değişiklikle Cumhurbaşkanının cezai sorumluluğu açıkça belirtilmiştir. Bu maddede yapılan değişiklikle Cumhurbaşkanı hakkında bir suç işlemesi nedeniyle nasıl soruşturma açılabileceği düzenlenmiştir. Cumhurbaşkanı hakkında soruşturma önergesi ancak Türkiye Büyük Millet Meclisi üye tamsayısının salt çoğunluğunun kararıyla verilebilecektir. Bu önerge en geç bir ay içinde Türkiye Büyük Millet Meclisi'nde görüşüleceği ve üye tam sayısının 3/5'inin oyu ile soruşturma açılabileceği belirtilmiştir. Soruşturma açılması kararı verildikten sonra Türkiye Büyük Millet Meclisi'ndeki partilerin temsili oranında bir komisyon oluşturup komisyonun hazırladığı raporun Meclise dağıtımı sonrasında yapılan oylamada Türkiye Büyük Millet Meclisi; üye tam sayısının 2/3'nün olumlu oyuyula Yüce Divan'a gönderme kararı verilebilir. Hakkında bu şekilde bir karar verilen Cumhurbaşkanı seçim kararı alamamaktadır. Ayrıca eğer Cumhurbaşkanı Yüce Divan'da seçilmesine engel bir suçtan mahkûm edilirse görevi sona erer. Cumhurbaşkanı, görevi sırasında yaptıklarından görevi sona erdiğinde de sorumludur.

106. maddede yapılan değişiklikle Cumhurbaşkanı'nın kendisine birden fazla yardımcı atayabileceği belirtilmiştir. Yine bu madde de Cumhurbaşkanlığı makamının boşalması halinde Cumhurbaşkanlığ seçiminin 45 gün içinde yapılacağı, Cumhurbaşkanı seçilene kadar Cumhurbaşkanı yardımcısının makama vekâlet edeceği, genel seçimlere az bir süre kalmışsa (1 yıl ve daha az) Cumhurbaşkanı seçimi ile TBMM seçimlerinin birlikte yapılacağı, genel seçimlere az bir süre kalmışsa (1 yıl ve daha az) görevi devam eden Cumhurbaşkanının TBMM seçim tarihine kadar görevine devam edeceği, bakanların ve Cumhurbaşkanı yardımcılarının milletvekili seçilme yeterliliğine sahip olmak şartıyla Cumhurbaşkanınca atanıp görevden alınabileceği, bakanların ve Cumhurbaşkanı yardımcılarının TBMM ile herhangi bir ilişkilerinin (üyelik anlamında) olamayacağı ve Cumhurbaşkanına karşı sorumlu oldukları, bakanlıkların kurulması ve kaldırılması gibi işlemlerin Cumhurbaşkanlığı kararnamesiyle yapılacağı belirtilmiştir.

116. maddede yapılan değişiklikle Türkiye Büyük Millet Meclisi'nin üye tam sayısının 3/5 çoğunluğu ile seçimlerin yenilenmesine karar verilebileceği ve bu durumda TBMM seçimleri ile Cumhurbaşkanlığı seçinin bir arada yapılabileceği belirtilmiştir. Yine bu maddede: Cumhurbaşkanı'nın seçimleri yenileme kararı vermesi durumunda Cumhurbaşkanlığı seçimi ile TBMM genel seçimlerinin birlikte yapılacağı belirtilmiş̧ir. Ayrıca “Cumhurbaşkanı'nın ikinci görev döneminde TBMM tarafindan seçimlerin yenilenmesine karar verilirse, Cumhurbaşkanı bir defa daha aday olabilecektir. Bu durumda seçimlerin birlikte yenilenmesine karar verilen TBMM'nin ve Cumhurbaşkanı'nın yetki ve görevleri, yeni TBMM'nin ve Cumhurbaşkanı'nın göreve başlamasına kadar" sürecektir. 116. maddede yapılan değişiklikle Cumhurbaşkanı'nın olağanüstü hal yönetimi ile ilgili yetkileri güncellenmiştir. Cumhurbaşkanı'nın çeşitli durumlarda olağanüstü hal ilan edebileceği düzenlenmiştir. 161. maddede yapılan değişiklikle bütçe ve kesin hesap kanununun Cumhurbaşkanlığınca hazırlanıp Meclis'e sunulacağı belirtilmiştir.

Genel hatlarıyla 17 Nisan 2017 referandumunda yapılan değişiklikler yukarıda belirtilmiştir. Referandumdan sonra çıkarılan 2018 tarihli 698-699-700 ve 703 sayılı Kanun Hükmünde Kararnameler ile de değişiklikler yapılmıştır. Yapılan değişikliklerde mülga olan Başbakan ve Bakanlar Kurulu ibarelerinin yerine Cumhurbaşkanı; Tüzük ibaresinin yerine yönetmelik ya da Cumhurbaşkanınca çıkarılan yönetmelik; başbakanlık müsteşarı ibaresinin yerine en yüksek dereceli devlet memuru ibaresi getirilmiştir.

Sonuç olarak 2007 yılında başlayan başkanlık sistemine doğru evriliş 2017 yılında yapılan Anayasa değişikliği referandumu ile sona ermiştir. 16 Nisan 2017 yılından sonra yeni sisteme uyumlaştırma amaciyla pek çok kanun ve kanun hükmünde kararname çıkarılmıştır. Fakat yeni sisteme entegre olma noktasında yapılan en önemli değişiklikler Cumhurbaşkanlığı Kararnameleri ile olmuştur. İlk olarak 10.07.2018 tarihinde 1 No'lu Cumhurbaşkanlığı Kararnamesi Resmi Gazete'de yayımlanmıştır. En son (17.07.2021 tarihi itibariyle) Cumhurbaşkanlığı Kararnamesi (80 nolu) 14.07.2021 tarihinde Resmi Gazete'de yayımlanmıştır. Bu kararnamelerin pek çoğunda Cumhurbaşkanlığı teşkilatı yeniden düzenlenmiştir. $\mathrm{Bu}$ düzenlemelerde yeni kurum ve kuruluşlar ortaya çıkmıştır. Cumhurbaşkanlığı İdari İşler Başkanlığı da bu kurumlardan birisidir. Cumhurbaşkanlığı hükümet sistemi, sonrasında Cumhurbaşkanlığı teşkilatında yapılan değişiklikler son bölüm olan üçüncü bölümde (4. nolu ana başlık) derinlemesine incelenmiştir. 


\section{CUMHURBAŞKANLIĞI TEŞKILATI VE CUMHURBAŞKANLIĞI İDARİ İŞLER BAŞKANLIĞI}

Cumhurbaşkanlığı hükümet sistemine geçişle birlikte idari yapıdaki düzenlemelerin ilki 10 Temmuz 2018 tarihinde Resmi Gazete'de yayımlanarak yürürlüğe giren "Cumhurbaşkanlı̆̆g Kararnameleri” ile yapılmıştır. Çalışmanın hazırlandığı tarih itibariyle 80 tane Cumhurbaşkanlığı Kararnamesi Resmi Gazete'de yayımlanmıştır ${ }^{2}$. Cumhurbaşkanlığı hükümet sisteminin işleyişini oluşturan omurganın yani teşkilat yapısının anlaşılması için bu 80 Cumhurbaşkanlığı Kararnamesi'nin incelenmesi gerekmektedir ${ }^{3}$. Çalışma sürecinde yapılan kararname içeriği incelemeleri sonucunda Şekil.2 oluşturulmuştur.

Şeki1.2 incelendiğinde Cumhurbaşkanlığı hükümet sisteminde, Cumhurbaşkanlığı teşkilatı daha rahat ve net bir şekilde anlaşılabilmektedir. Öncelikle belirtmek gerekir ki Cumhurbaşkanlığı teşkilatı ile ilgili ilk derinlemesine düzenleme 10 Temmuz 2018 tarihinde yayımlanan 1 No'lu Cumhurbaşkanlığı Teşkilatı Hakkında Cumhurbaşkanlığı Kararnamesidir. Bu kararname 539 maddeden oluşmaktadır. Bu kararname ile Özel Temsilci, Cumhurbaşkanı Özel Kalem Müdürlüğü, Politika Kurulları, Cumhurbaşkanı Danışmanı ve Başdanışmanı, Bakanlıklar, İdari İşler Başkanlığı, Cumhurbaşkanı Yardımcıları, Cumhurbaşkanlığına Bağlı Kurum ve Kuruluşlar ve Ofisler düzenlenmiştir. Şekil.2'de belirtilen kuruluşlardan sadece Yüksek İstişare Kurulu (YİK) düzenleme 10 Temmuz 2018 tarihinde yayımlanan 1 No'lu Cumhurbaşkanlığı Teşkilatı Hakkında Cumhurbaşkanlığı Kararnamesi'nin ilk halinde düzenlenmemiştir. YİK, 15 Mayıs 2019 tarihli 36 No'lu, Cumhurbaşkanlığı Teşkilatı Hakkında Cumhurbaşkanlığı Kararnamesi’nde Değişiklik Yapılmasına Dair Cumhurbaşkanlığg Kararnamesi ile kurulmuştur.

Şekil 2. Yeni Sistemde Cumhurbaşkanlığı Teşkilatı

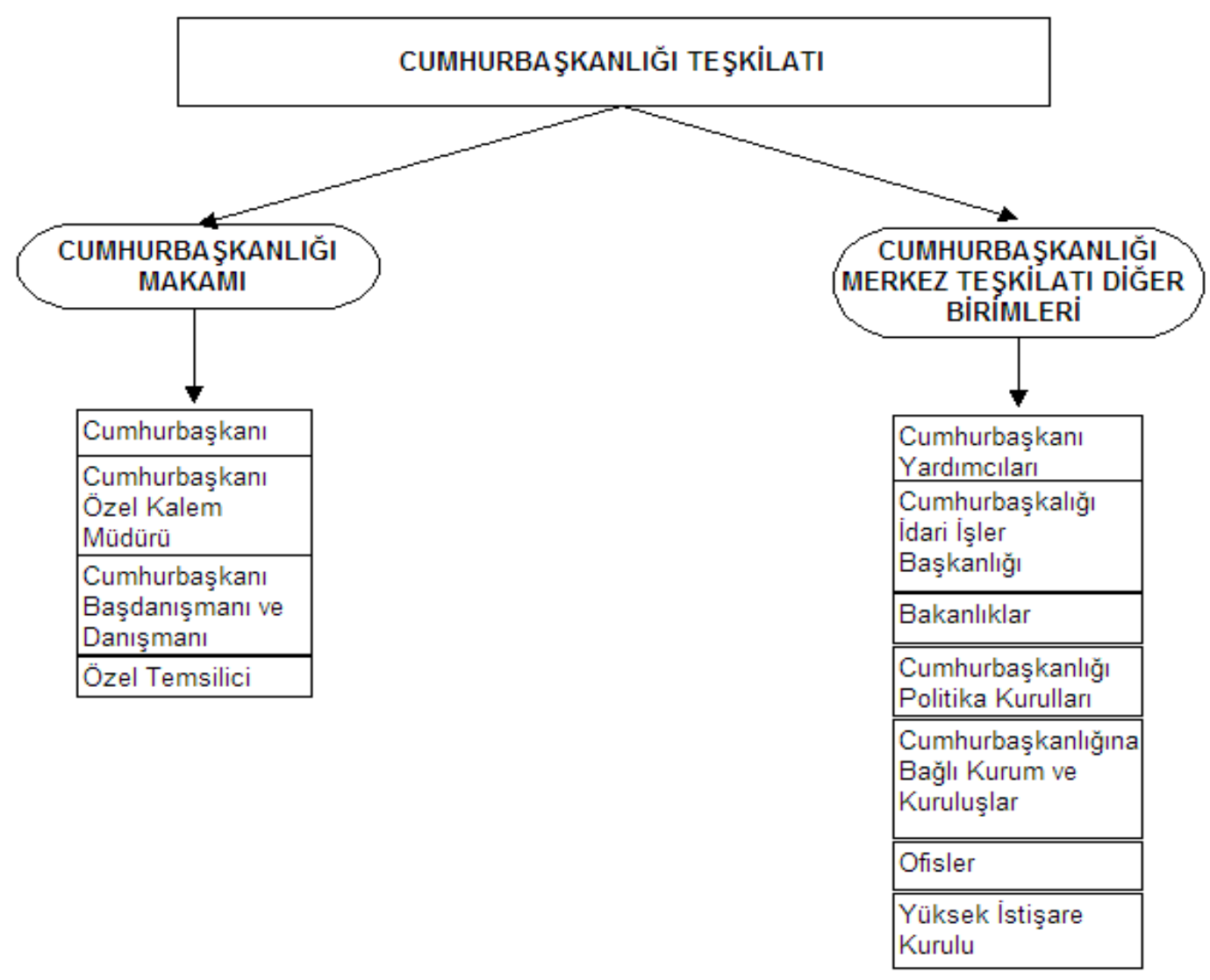

Kaynak: Yazar tarafından 80 adet kararnamenin taranması ile oluşturulmuştur.

Şekil.2'de belirtilen Cumhurbaşkanlığı teşkilatı birimleri, Tablo.1'de belirtilen Cumhurbaşkanlığı kararnameleri ile tesis edilmiş ve son halini almıştır.

2 Bu veri, Resmi Gazete’nin mevzuat arama kısmından “Cumhurbaşkanlı̆̆ı Kararnameleri” taranarak hazıranmıştır. Bilgi için bkz: https://www.resmigazete.gov.tr/.

3 Çalışmanın yazarı 5 aylık bir çalışma sonucu 80 Cumhurbaşkanlığı Kararnamesi’ni taramıştır. 
AKCAGÜNDÜZ, Emre - Cumhurbaşkanlığı Hükümet Sisteminde Kilit Bir Aktör: Cumhurbaşkanlığı İdari İşler Başkanlığı

Tablo 1. Cumhurbaşkanlığı Teşkilatını Düzenleyen Kararnameler

\begin{tabular}{|c|c|c|}
\hline $\begin{array}{l}\text { Kararname } \\
\quad \text { No }\end{array}$ & Kararname Adı & $\begin{array}{l}\text { Resmi Gazete } \\
\text { Yayım Tarihi }\end{array}$ \\
\hline 1 & Cumhurbaşkanlığı Teşkilatı Hakkında Cumhurbaşkanlığı Kararnamesi & 10.07.2018 \\
\hline 24 & $\begin{array}{l}\text { Cumhurbaşkanlığı Teşkilatı Hakkında Cumhurbaşkanlığı Kararnamesinde Değişiklik Yapılmasına } \\
\text { Dair Cumhurbaşkanlığı Kararnamesi }\end{array}$ & 28.12.2018 \\
\hline 28 & $\begin{array}{l}\text { Cumhurbaşkanlığı Teşkilatı Hakkında Cumhurbaşkanlığı Kararnamesinde Değişiklik Yapılmasına } \\
\text { Dair Cumhurbaşkanlığı Kararnamesi }\end{array}$ & 18.01.2019 \\
\hline 32 & $\begin{array}{l}\text { Cumhurbaşkanlığı Teşkilatı Hakkında Cumhurbaşkanlığı Kararnamesi İle Genel Kadro ve Usulü } \\
\text { Hakkında Cumhurbaşkanlığı Kararnamesinde Değişiklik Yapılmasına Dair Cumhurbaşkanlığı } \\
\text { Kararnamesi }\end{array}$ & 18.04.2019 \\
\hline 36 & $\begin{array}{l}\text { Cumhurbaşkanlığı Teşkilatı Hakkında Cumhurbaşkanlığı Kararnamesinde Değişiklik Yapılmasına } \\
\text { Dair Cumhurbaşkanlığı Kararnamesi }\end{array}$ & 15.05 .2019 \\
\hline 45 & $\begin{array}{l}\text { Cumhurbaşkanlığı Teşkilatı Hakkında Cumhurbaşkanlığı Kararnamesinde Değişiklik Yapılmasına } \\
\text { Dair Cumhurbaşkanlığı Kararnamesi }\end{array}$ & 12.09.2019 \\
\hline 46 & $\begin{array}{l}\text { Cumhurbaşkanlığı Teşkilatı Hakkında Cumhurbaşkanlığ Kararnamesi ile Bakanlıklara Bağlı, } \\
\text { İlgili, İlişkili Kurum ve Kuruluşlar ile Diğer Kurum ve Kuruluşların Teşkilatı Hakkında } \\
\text { Cumhurbaşkanlığı Kararnamesinde Değişiklik Yapılmasına Dair Cumhurbaşkanlığ Kararnamesi }\end{array}$ & 13.10.2019 \\
\hline 48 & $\begin{array}{l}\text { Cumhurbaşkanlığı Teşkilatı Hakkında Cumhurbaşkanlığı Kararnamesinde Değişiklik Yapılmasına } \\
\text { Dair Cumhurbaşkanlığı Kararnamesi }\end{array}$ & 24.10.2019 \\
\hline 53 & $\begin{array}{l}\text { Cumhurbaşkanlığı Teşkilatı Hakkında Cumhurbaşkanlığı Kararnamesinde Değişiklik Yapılmasına } \\
\text { Dair Cumhurbaşkanlığı Kararnamesi }\end{array}$ & 26.01.2019 \\
\hline 56 & $\begin{array}{l}\text { Cumhurbaşkanlığı Teşkilatı Hakkında Cumhurbaşkanlığı Kararnamesinde Değişiklik Yapılmasına } \\
\text { Dair Cumhurbaşkanlığı Kararnamesi }\end{array}$ & 17.01.2020 \\
\hline 59 & $\begin{array}{l}\text { Cumhurbaşkanlığı Teşkilatı Hakkında Cumhurbaşkanlığı Kararnamesinde Değişiklik Yapılmasına } \\
\text { Dair Cumhurbaşkanlığı Kararnamesi }\end{array}$ & 14.04 .2020 \\
\hline 61 & $\begin{array}{l}\text { Cumhurbaşkanlığı Teşkilatı Hakkında Cumhurbaşkanlığı Kararnamesinde Değişiklik Yapılmasına } \\
\text { Dair Cumhurbaşkanlığı Kararnamesi }\end{array}$ & 13.05.2020 \\
\hline 64 & $\begin{array}{l}\text { Cumhurbaşkanlığı Teşkilatı Hakkında Cumhurbaşkanlığı Kararnamesinde Değişiklik Yapılmasına } \\
\text { Dair Cumhurbaşkanlığı Kararnamesi }\end{array}$ & 10.06.2020 \\
\hline 70 & $\begin{array}{l}\text { Cumhurbaşkanlığı Teşkilatı Hakkında Cumhurbaşkanlığı Kararnamesi ile Bazı Cumhurbaşkanlığı } \\
\text { Kararnamelerinde Değişiklik Yapılmasına Dair Cumhurbaşkanlığı Kararnamesi }\end{array}$ & 06.02 .2021 \\
\hline 75 & $\begin{array}{l}\text { Cumhurbaşkanlığı Teşkilatı Hakkında Cumhurbaşkanlığı Kararnamesinde Değişiklik Yapılmasına } \\
\text { Dair Cumhurbaşkanlığı Kararnamesi }\end{array}$ & 30.06 .2021 \\
\hline 78 & $\begin{array}{l}\text { Cumhurbaşkanlığı Teşkilatı Hakkında Cumhurbaşkanlığı Kararnamesinde Değişiklik Yapılmasına } \\
\text { Dair Cumhurbaşkanlığı Kararnamesi }\end{array}$ & 06.07 .2021 \\
\hline 79 & $\begin{array}{l}\text { Cumhurbaşkanlığı Teşkilatı Hakkında Cumhurbaşkanlığı Kararnamesinde Değişiklik Yapılmasına } \\
\text { Dair Cumhurbaşkanlığı Kararnamesi }\end{array}$ & 07.07 .2021 \\
\hline 80 & $\begin{array}{l}\text { Bazı Cumhurbaşkanlığı Kararnamelerinde Değişiklik Yapılması Hakkında Cumhurbaşkanlığı } \\
\text { Kararnamesi }\end{array}$ & 14.07.2021 \\
\hline
\end{tabular}

Kaynak: Yazar tarafından 80 adet kararnamenin taranması ile oluşturulmuştur.

Şekil 2'de belirtilen ve 10 Temmuz 2018 tarihinde yayımlanan 1 No'lu Cumhurbaşkanlığı Teşkilatı Hakkında Cumhurbaşkanlığı Kararnamesi (2. madde) ile düzenlenen ilk birim Cumhurbaşkanlığı Özel Kalem Müdürlüğü’dür. Cumhurbaşkanı Özel Kalem Müdürlüğü’nün görevleri şunlardır;

- “Cumhurbaşkanı'nın Devlet Arşivlerine ve Milli Saraylara ilişkin vermiş olduğu emir, talimat, iş ve işlemleri yapmak

- Cumhurbaşkanlığı makamına ilişkin ihtiyaç duyulan hizmetleri yapmak,

- Cumhurbaşkanı'nın özel ve resmi yazışmalarını yapmak,

- Cumhurbaşkanının gezi (yurt dışı ve yurt içi) tören vb. organizasyonlarını yapmak ve yürütmek,

- Cumhurbaşkanlığı makamının kurumsal iletişim hizmetleri, halkla ilişkiler ve protokol işlerini (hizmetlerini) yürütmek, 
- Cumhurbaşkanının Milli Saraylar ile ilgili iş ve işlemlerini yapmak bu kurum ile olan ilişkilerini yönetmek,

- Cumhurbaşkanı'nın Devlet Arşivleri ile ilgili iş ve işlemlerini yapmak bu kurum ile olan ilişkilerini yönetmek,

- Cumhurbaşkanı tarafindan (gerekli görüldüğünde) verilen diğer görevleri yapmak.”

Cumhurbaşkanı Özel Kalem Müdürü’nün yukarıda açıkça görüldüğü gibi pek çok önemli görevi vardır. Bu durum nedeniyle ihtiyaç halinde Cumhurbaşkanı Özel Kalem Müdür Yardımcıları görevlendirilebilmektedir. Yine Özel Kalem Müdürlüğü ihtiyaç halinde çeşitli yerlerde çalışma büro açabilmektedir. Son olarak Cumhurbaşkanı Özel Kalem Müdürü'ne Büyükelçi unvanı verilmektedir. Bu unvanın verilmesinin nedeni; "Büyükelçilerin, görevli bulunduğu ve akredite edildiği ülkelerde Türkiye Cumhuriyeti Devletini, Cumhurbaşkanını temsil etmeleridir. Büyükelçi, görev yaptığı ülkede büyükelçiliğge bă̆gl tüm birimlerin amiridir" (www.mfa.gov.tr, 2021). Özel Kalem Müdürü'nün belirtilen ayrıcalıklardan yararlanması için bu unvan kendisine verilmiştir.

10 Temmuz 2018 tarihinde yayımlanan 1 No’lu Cumhurbaşkanlığı Teşkilatı Hakkında Cumhurbaşkanlığı Kararnamesi (3. madde) ile düzenlenen ikinci birim Cumhurbaşkanı Başdanışmanı ve Danışmanı'dır. Başdanışman ve danışmanlar, Cumhurbaşkanı'na danışmanlık yapmak amacıyla, Cumhurbaşkanınca atanmaktadırlar. Başdanışman ve danışmanlar özellikle uzmanlık gerektiren spesifik konularda (dış politika, eğitim, ekonomi, hukuk vb.) Cumhurbaşkanı'na danışmanlık yapmaktadırlar. Aynı kararname (4. madde) ile düzenlenen üçüncü birim, Özel Temsilci’dir. Özel Temsilci, idari teşkilat yapısında yeni bir birimdir. Bu birimin temel amacı, Cumhurbaşkanı'nın yabancı ülkelerde ya da uluslararası kuruluşlarda temsilini sağlamaktır. Özellikle uluslararası platformlarda uzmanlık gerektiren toplantılarda Özel Temsilci, Cumhurbaşkanı'nı temsil edebilmektedir. Özel Temsilci'ye, büyükelçilerin yararlandığı muafiyetlerden yararlanması için Büyükelçi unvanı verilebilmektedir. Bu unvan, Özel Temsilcilik görevi süresiyle sınırlıdır.

1 No'lu Cumhurbaşkanlığı Teşkilatı Hakkında Cumhurbaşkanlığı Kararnamesi'ne, 15 Mayıs 2019 tarihli 36 No'lu Cumhurbaşkanlığı Teşkilatı Hakkında Cumhurbaşkanlığı Kararnamesi'nde Değişiklik Yapılmasına Dair Cumhurbaşkanlığı Kararnamesi ile 4/A maddesi eklenmiştir. Bu madde ile Yüksek İstişare Kurulu kurulmuştur. $\mathrm{Bu}$ Kurul, "Millete ve devlete hizmeti geçmiş, bilgi ve birikim sahibi kişilerin kazanımlarından istifade edilebilmesi amacıyla oluşturulmuştur." Kurul'un üyeleri bizzat Cumhurbaşkanınca atanmaktadır. Yine Kurul'un çalışma şekli, Kurul üyelerine yapılacak olan ödemeler, Cumhurbaşkanınca belirlenmektedir. Bu Kurul'da idari teşkilat yapısında yeni bir yapılanmadır. Kurul'un en temel amacı, geçmişte önemli görevlerde bulunan kişilerin tecrübelerinden yararlanmaktır.

Şekil.2'de belirtilen 1 No'lu Cumhurbaşkanlığı Teşkilatı Hakkında Cumhurbaşkanlığı Kararnamesi (17-19. maddeler) ile düzenlenen beşinci birim Cumhurbaşkanı yardımcılarıdır. Cumhurbaşkanı yardımcıları, Cumhurbaşkanının verdiği görevleri yapmakla yükümlüdürler. Cumhurbaşkanı yardımcıları, çeşitli nedenlerle Cumhurbaşkanlığı makamının boşalması halinde Cumhurbaşkanına vekâlet ederler. Cumhurbaşkanı yardımcıları, Cumhurbaşkanına karşı sorumludurlar. Aynı kararname (23-36. maddeler) ile düzenlenen altıncı birim Cumhurbaşkanlığı Politika Kurullarıdır ${ }^{4}$. Bu kurulların başkanı, Cumhurbaşkanıdır. Her bir kurul üç üyeden oluşmaktadır. Kurulun üyelerini Cumhurbaşkanı seçmektedir. Bu Kurullara seçilen üyeler, ilgili Kurullara katkı yapacak uzman kişilerdir. Kurulların temel amacı, kamu politikalarının yapımı sürecinde kararlar ve oluşturulacak politikalarla ilgili öneriler geliştirmektir. Yine Kurullar, görev alanları ile ilgili konularda talep olması halinde kamu kurumlarına görüş vermektedir. Kurullar, ihtiyaç olması halinde bütün kamu kurum ve kuruluşları, sivil toplum örgütleri, özel sektör temsilcileri ve alanında uzman kişileri toplantılarına davet edip görüş alışverişinde bulunabilirler. Kurullar, yaptıkları faaliyetlerle ilgili Cumhurbaşkanına rapor sunmaktadır.

1 No'lu Cumhurbaşkanlığ 1 Teşkilatı Hakkında Cumhurbaşkanlığı Kararnamesi (37. madde) ile düzenlenen yedinci birim Cumhurbaşkanlığına Bağlı Kurum ve Kuruluşlardır. Toplam 10 tane kurum ve kuruluşun Cumhurbaşkanlığına bağlı olduğu 1 No'lu Cumhurbaşkanlığı Kararnamesi'nde belirtilmiştir. Bu kurum ve kuruluşlar şunlardır: Milli Güvenlik Kurulu Genel Sekreterliği, Devlet Arşivleri Başkanlığı, Türkiye Varlık

4 Toplam dokuz adet politika kurulu bulunmaktadır. Bunlar; Sağlık ve Gıda Politikaları Kurulu, Kültür ve Sanat Politikaları Kurulu, Eğitim ve Öğretim Politikaları Kurulu, Ekonomi Politikaları Kurulu, Bilim, Teknoloji ve Yenilik Politikaları Kurulu, Sosyal Politikalar Kurulu, Güvenlik ve Dış Politikalar Kurulu, Yerel Yönetim Politikaları Kurulu, Hukuk Politikaları Kurulu'dur. 
Fonu, Diyanet İşleri Başkanlığı, Milli İstihbarat Teşkilatı Başkanlığı, Savunma Sanayi Başkanlığı, Devlet Denetleme Kurulu, İletişim Başkanlığı, Strateji ve Bütçe Başkanlığı, Milli Saraylar İdaresi Başkanlığı'dır.

1 No'lu Cumhurbaşkanlığı Teşkilatı Hakkında Cumhurbaşkanlığı Kararnamesi (38-520. maddeler) ile düzenlenen sekizinci birim bakanlıklardır. Cumhurbaşkanlığı hükümet sistemi ile birlikte bakanlıkların sayısı azaltılmıştır. Haziran 2021 itibariyle 17 adet bakanlık bulunmaktadır. Bu bakanlıkların teşkilat yapısı ve görevleri 1 No'lu Cumhurbaşkanlığı Teşkilatı Hakkında Cumhurbaşkanlığg Kararnamesi ayrıntılı bir şekilde düzenlenmiştir. Kararnamede en çok hüküm bakanlıklarla ilgilidir.

Son olarak, 1 No'lu Cumhurbaşkanlığı Teşkilatı Hakkında Cumhurbaşkanlığg Kararnamesi (525-527. maddeler) ile düzenlenen dokuzuncu birim Ofislerdir ${ }^{5}$. Cumhurbaşkanlığı Ofisleri daha önce idari teşkilat yapısında benzeri bulunmayan bir yapılanmadır. Ofisler, görev alanlarıyla ilgili konularda kendilerine verilen görevleri yerine getirmekle yükümlü birimlerdir. Bu birimler hem Cumhurbaşkanına bağlı hem de ayrı kamu tüzel kişilikleri olan oluşumlardır. Kamu tüzel kişiliğine sahip olmalarının yanında özel bütçeli, idarî ve malî özerkliğe sahiptirler. Dört adet Ofis bulunmaktadır. Bunlar: Yatırım, Finans Ofisi, Dijital Dönüşüm ve İnsan Kaynakları Ofisi'dir. Ofislerin merkezi Ankara'dadır. Ancak Ofisler, gerekli görmesi halinde yurt içinde ve yurt dışında çalışma bürosu açabilmektedir.

\subsection{Cumhurbaşkanlığı İdari İşler Başkanlığı}

1 No'lu Cumhurbaşkanlığı Teşkilatı Hakkında Cumhurbaşkanlığı Kararnamesi (5-16. maddeler) ile Cumhurbaşkanlığı İdari İşler Başkanlığı düzenlenmiştir. Şekil.3'de Cumhurbaşkanlığı İdari İşler Başkanlığ 1 teşkilat yapısı gösterilmektedir.

Şekil 3. Cumhurbaşkanlığı İdari İşler Başkanlığı Teşkilat Yapısı

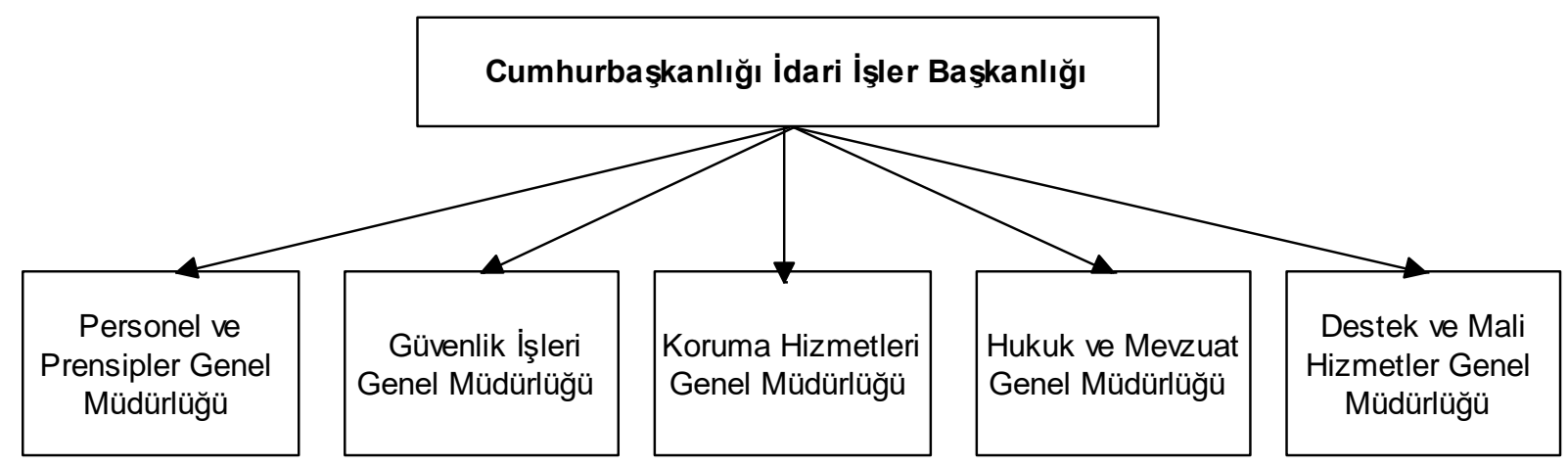

Kaynak: Yazar tarafından 1 No’lu Cumhurbaşkanlığg Kararnamesi çerçevesinde hazırlanmıştır.

İdari İşler Başkanlığı’nın başında İdari İşler Başkanı bulunmaktadır. İdari İşler Başkanı, idari teşkilat yapısı açısından oldukça önemli bir yere sahiptir. Kendisi en yüksek dereceli devlet memuru sıfatına sahiptir. İdari İşler Başkanı, Cumhurbaşkanlığı Özel Kalem Müdürü, Başdanışmanlar, Danışmanlar ve Genel Müdürler hariç; diğer Cumhurbaşkanlığı personelini atar veya görevlendirilir. İdari İşler Başkanı, hem mevzuatça belirtilen hem de Cumhurbaşkanınca verilen görevleri yerine getirmekle yükümlüdür. İdari İşler Başkanının görevleri 1 No'lu Cumhurbaşkanlığı Teşkilatı Hakkında Cumhurbaşkanlığı Kararnamesinin 6. maddesinde şu şekilde belirtilmiştir;

- “Cumhurbaşkanı'nın Anayasa'da belirtilen görev ve yetkilerini kullanması sürecinde gerekli hizmetleri sunmak,

- Cumhurbaşkanlı̆̆ı'nın TBMM ile olan ilişkilerinin yürütülmesi sürecini yönetmek ve bu konuda gerekli çalışmaları yapmak,

- Kamu kurum ve kuruluşları arasında uyumlu bir çalışma düzeninin sağlanması için gerekli çalışmaları yapmak,

- Türkiye Cumhuriyeti Devleti idari teşkilat yapısının (Devlet Teşkilatı) etkin ve düzenli bir şekilde çalışması için gerekli kuralların ve prensiplerin belirlenmesi için çalışmalar yapmak,

5 Ofisler, idari teşkilat yapısında daha önce eşi bulunmayan atipik yapılanmalardır. Dört Ofis'inde önemli görevleri bulunmaktadır. Bu çalışmada İdari İşler Başkanlığı'na odaklanıldığ için Ofisler genel hatlarıyla incelenmiştir. 
- İç ve dış güvenlik ile terörle mücadelede kamu kurumları arasında gerekli koordinasyon ve iş birliğini sağlamak için çalışmalar yapmak,

- Cumhurbaşkanlığı neslinde yapılan çalışmaların, kamuoyundaki etkisini takip etmek ve değerlendirme çalışmalarını yapmak."

İdari İşler Başkanlığının Şekil.3'de görüldüğü gibi beş adet alt birimi bulunmaktadır. Bu birimler ve yapmakla yükümlü oldukları görevleri oldukça önemlidir. İlk olarak incelenecek olan alt birim Hukuk ve Mevzuat Genel Müdürlüğüdür. Bu birimin görevleri 1 No'lu Cumhurbaşkanlığı Teşkilatı Hakkında Cumhurbaşkanlığı Kararnamesi'nin 7. maddesinde şu şekilde belirtilmiştir;

- “TBMM tarafından kabul edilen yasaların şekil ve esas açısından Anayasa'ya uygun olup olmadığı ile ilgili gerekli denetimi yapmak,

- TBMM İç Tüzüğünün ya da kanunların, bir kısmının veya bütününün Anayasa'ya esas ve şekil bakımından aykırı olmaları durumunda, Anayasa Mahkemesine açılacak iptal davasının hazırlıklarını yapmak,

- Cumhurbaşkanınca halkoylamasına sunulması gereken Anayasa değişiklikleri ile ilgili kanunların hazırlanmasına dair işlemleri yapmak,

- Cumhurbaşkanlığı Kararnameleri ile kanunların yayımlanması ile ilgili işlemleri yapmak,

- Resmi Gazete'nin çıkarılması (yayımlanması) işlemlerini yapmak,

- TBMM Başkanlığına, milletlerarası anlaşmaların yasayla uygun bulunması için gönderilmesine ilişkin işlemleri yapmak,

- Kamu kurumları ve kuruluşları ile bakanlıkların hazırladığı mevzuat taslaklarını; genel hukuk kurallarına, Anayasa'ya, Cumhurbaşkanlığı Kararnameleri'ne ve diğer mevzuat hükümlerine uygunluk açısından incelemek,

- Çeşitli nedenlerle (sağlık sorunları, sakatlık, yaşlanma gibi) hükümlülerin cezalarının kaldırılması ya da hafifletilmesi ile işlemleri yapmak bu konu ile ilgili bilgileri Adalet Bakanlığına bildirmek,

- Cumhurbaşkanınca çıkarılan yürütmenin düzenleyici işlerinden olan Cumhurbaşkanlığı kararnameleri, Cumhurbaşkanlığı kararları ve yönetmelik taslaklarını hazırlamak.”

İkinci olarak incelenecek olan alt birim Personel ve Prensipler Genel Müdürlüğüdür. Bu birimin görevleri 1 No'lu Cumhurbaşkanlığı Teşkilatı Hakkında Cumhurbaşkanlığı Kararnamesi'nin 8. maddesinde şu şekilde belirtilmiştir ;

- "Türkiye Cumhuriyeti Devleti idari teşkilat yapısının (Devlet Teşkilatı) etkin ve düzenli bir şekilde faaliyet göstermesi için gerekli prensiplerin belirlenmesi, emirlerin verilmesi ve önlemlerin alınmasını sağlamak,

- Türkiye Cumhuriyeti Devleti idari teşkilat yapısının (Devlet Teşkilatı) birimleri arasında koordinasyonun sağlanması için gerekenleri yapmak,

- Cumhurbaşkanına vekâlet işlemlerini yapmak,

- Bakanlar ile Cumhurbaşkanı yardımcılarının atanmaları, görevden alınmaları ve vekâlet işlemlerini yapmak,

- TBMM üyelerinin dokunulmazlıklarının kaldırılması ve TBMM seçimlerinin yenilenmesiyle ilgili işlemleri yapmak,

- Cumhurbaşkanınca yapılan atamaların (üst kademe kamu yöneticileri ve diğer atama ve seçme işlemlerini) mevzuata (Anayasa, yasa, hukukun genel ilkeleri ve Cumhurbaşkanlığl kararnameleri) uygunluk açısından incelemek ve gerekli işlemleri yapmak,

- Devletin işleyişinde (sevk ve idaresinde) görevli ya da görev alacak üst kademe kamu yöneticiler hakkında biyografi ve sicil özetlerini tutmak, haklarında gerekli bilgiyi toplamak,

6 Burada önemli görülen görevler belirtilmiştir. Birimin bu görevler haricinde farklı görevler de mevcuttur. Bu konu ile ilgili 1 nolu Cumhurbaşkanlığı Kararnamesine bakılabilir. 
AKCAGÜNDÜZ, Emre - Cumhurbaşkanlığı Hükümet Sisteminde Kilit Bir Aktör: Cumhurbaşkanlığı İdari İşler Başkanlığı

- Kamu yönetimi yapısının geliştirilmesi ile ilgili politikaların, hedeflerin ve önlemlerin belirlenmesi için gerekli araştırmaları yapmak ya da yaptırmak. Bu araştırmalar sonucunda oluşan verileri rapor haline getirmek ve Cumhurbaşkanına sunmak,

- İlişkili, bağlı ya da ilgili kuruluşların, bakanlıklar ya da Cumhurbaşkanlığı ile ilgilendirilmelerine dair işlemleri yapmak,

- Cumhurbaşkanının özlük ile ilgili iş ve işlerini yerine getirmek,

- Cumhurbaşkanlığı (merkez) teşkilatının; özlük, tayin, personelin yetiştirilmesi/geliştirilmesi, nakil ve emeklilik işlemlerine bakmak,

- Kamu personelinin, istihdam politikasını, personelle ilgili mevzuat çalışmalarını, işe alım süreçlerini, unvan ve kadro standartlarının belirlenmesi gibi iş ve işlemleri yapmak,

- Memurlara (diğer kamu görevliler de dâhil) ilişkin mevzuat hükümlerinin uygulanması ile ilgili bütün süreçleri takip etmek,

- Kamu personelinin istihdamı ve işe kabul sürecinde uygulanacak kaidelerin (usul ve esasların) belirlenmesini sağlamak,

- Kamu kurum ve kuruluşlarının unvan ve kadro standartlarının belirlenmesi, görev tanımları ve iş analizlerinin yapılması ile ilgili çalışmalar yapmak,

- Kamu personelinin yurt içi ve yurt dışı seyahat yevmiyeleriyle daimi görevle yabancı ülkede bulunan memurların maaşları ile ilgili konularını düzenlemek,

- Kamu personelinin yurt içinde ve yurt dışında eğitim ve yetiştirilmeleri ile ilgili çalışmaları yapmak ve bu çalışmaları denetlemek"

Üçüncü olarak incelenecek olan alt birim, Güvenlik İşleri Genel Müdürlüğüdür. Bu birimin görevleri 1 No'lu Cumhurbaşkanlığı Teşkilatı Hakkında Cumhurbaşkanlığı Kararnamesi'nin 9. maddesinde sayılmıştır. Birimin ana görevi;

"Devletin güvenlik politika ve stratejileri ile ilgili kamu kurum ve kuruluşlart ile koordinasyonu sağlamak, belirlenen politikaların uygulamasin izlemek, değerlendirmek ve raporlamaktır. Yine benzer şekilde, olağanüstü hâl ilan edilen bölgelerde, olağanüstü hâl ilanına esas olan konularda bilgileri derlemek, değerlendirmek ve bu hususlarda koordinasyonu sağlamaktır."

Dördüncü olarak incelenecek olan alt birim, Destek ve Mali Hizmetler Genel Müdürlügüdür. Bu birimin görevleri 1 No'lu Cumhurbaşkanlığı Teşkilatı Hakkında Cumhurbaşkanlığı Kararnamesi'nin 10. maddesinde sayılmıştır. Bu birimin ana görevi;

"Ilgili kanunlar çerçevesinde Cumhurbaşkanlı̆̆ının kiralama ve satın alma işlerini yürütmek, temizlik, aydınlatma, ısitma, onarım, taşıma ve benzeri hizmetleri yapmak veya yaptırmak, Cumhurbaşkanlı̆̆ Merkez Teşkilatı taşınır ve taşınmazlarına ilişskin işlemleri ilgili mevzuat çerçevesinde yürütmektir."

Beşinci olarak incelenecek olan alt birim, Koruma Hizmetleri Genel Müdürlüğüdür. Bu birim, 10 Ocak 2019 yılında yayımlanan 27 No'lu Cumhurbaşkanlığ 1 Kararnamesi ile kurulmuştur. Kararnameye göre, bu birimin personeli, "İdari İsler Başkanlı̆ııın talebi üzerine Emniyet, Jandarma veya Sahil Güvenlik Hizmetleri sınıflarına mensup olanlar arasından İçişleri Bakanliğınca görevlendirilir.” Bu birimin görevleri 1 No'lu Cumhurbaşkanlığı Teşkilatı Hakkında Cumhurbaşkanlığı Kararnamesi’nin 10/A maddesinde şu şekilde belirtilmiştir;

"Cumhurbaşkanı ve aile fertleri ile Cumhurbaşkanı Yardımcıları, Bakanlar, Cumhurbaşkanlı̆̆ı İdari Işsler Başkanı, Cumhurbaşkanının korunması talimatı verdiği kişilerin maddi ve manevi şahsiyetlerine yönelik her türlü saldırıya karşı gerekli koruma tertip ve tedbirlerini almak veya aldirmak."

Yukarıda verilen bilgilerde de açıkça görüldüğü gibi Cumhurbaşkanlığı İdari İşler Başkanlığı, Cumhurbaşkanlığı idari yapısı içerisindeki en kilit idari birimdir. Bu kanıya varılmasının çeşitli nedenleri vardır. Öncelikle Başkanlığın, 1 nolu Cumhurbaşkanlığı kararnamesinde sayılan görevlerine bakıldığında Türkiye Cumhuriyeti Devleti idari teşkilat yapısının ahenkli bir şekilde çalışması için gerekli düzenlemleri yapmakla yükümlü birim olduğu görülmektedir. Sadece bu görev bile Başkanlığın görev alanının nedenli kapsayıcı 
olduğunu gözler önüne sermektedir. Başkanlığın bir diğer kapsayıcı ve önemli görevi ise Türkiye'nin uzun yıllardır mücadele ettiği terör ile ilgilidir. Türkiye genelinde (dış ve iç güvenlik dâhil) terörle mücadele konusunda kurumların uyum içerisinde çalışmasından Başkanlık sorumludur. Türkiye'de idari kolluk makamlarının sayısı ve personel büyüklüğü göz önüne alındığında Başkanlığın nedenli önemli bir görevi olduğu kolayca anlaşılmaktadır.

İdari İşler Başkanlığı'nın dikkatlerden kaçan ve en önemli görevleri yerine getirmesini sağlayan iki alt birimi bulunmaktadır. Bunlar: Hukuk ve Mevzuat Genel Müdürlüğü ile Personel ve Prensipler Genel Müdürlügüdür. Bu birimlerden Hukuk ve Mevzuat Genel Müdürlüğü yukarıda da açıkça görüldüğü gibi Cumhurbaşkanlığı'nın mevzuatla ilgili (Cumhurbaşkanlığı kararnamesi ve kararları, kanunların Anayasa'ya uygunluğu, yönetmelik çıkarılması, milletlerarası anlaşmaların incelenmesi, halk oylaması, hükümlülerin affı gibi) bütün iş ve işlemlerini bu birim yapmaktadır. Personel ve Prensipler Genel Müdürlüğü ise her düzeyde kamu personelinin mevzuat, atama, özlük hakları vb. iş ve işlemlerini düzenleyen birimdir. Bu birim özellikle 21 Nisan 2021 tarihli Cumhurbaşkanlığı kararnamesi ile lağvedilen Devlet Personel Başkanlığı'nın görevlerini de devralmıştır. Kısacası kamu personeli ile ilgili bütün iş ve işlemler bu birimce yapılmaktadır. Son olarak Başkanlığın bir alt birimi olan Koruma Hizmetleri Genel Müdürlüğü, Cumhurbaşkanı ve ailesinin can güvenliği ile sorumlu birimdir. Kısacası Cumhurbaşkanının kendisi ve ailesinin dahi can güvenliği İdari İşler Başkanlığının sorumluluğundadır. Buraya kadar yapılan incelemede de açıkça görüldüğü gibi Cumhurbaşkanlığı İdari İşler Başkanlığı, Cumhurbaşkanlığı teşkilatında en önemli ve en kilit birimdir.

\section{SONUÇ}

17 Nisan 2017 Referandumu sonrası hayata geçirilen ve şimdiye kadar (17.07.2021 tarihi itibariyle) 80 Cumhurbaşkanlığı Kararnamesi ile şekillendirilen Cumhurbaşkanlığı Hükümet Sistemi ile ilgili pek çok farklı çalışma yapılmıştır. Bu çalışma, diğer çalışmalardan farklı olarak Cumhurbaşkanlığı Hükümet Sistemi ile ilgili çıkarılan kararnameleri inceleyerek sistemin teşkilat yapısını ve bu yapıda kilit bir görev alan İdari İşler Başkanlığını incelemiştir. Çalışmanın özellikle üçüncü bölümünde de açıkça görüldügüu gibi İdari İşler Başkanlığı, Cumhurbaşkanlığı hükümet sisteminin adeta omurgasıdır. Çalışma sürecinde yapılan inceleme ve araştırmalar sonucunda bazı tespitlerde bulunulmuştur. Bu tespitler, İdari İşler Başkanlığının neden önemli olduğu ve nasıl daha etkin çalışabileceği konuları üzerine yoğunlaşmıştır. Bu tespitler şu şekilde özetlenebilir;

- Herşeyden önce Cumhurbaşkanı ve aile fertleri ile Bakanlar ve Cumhurbaşkanı yardımcıları dâhil olmak üzere, Cumhurbaşkanlığı teşkilatı içerisindeki önemli görevlerde bulunan kişilerin can ve mal güvenliğinden İdari İşler Başkanlığı (Koruma Hizmetleri Genel Müdürlüğü vasitasıyla) sorumludur. Bu durum Başkanlığı önemini açıkça gözler önüne sermektedir.

- İdari İşler Başkanlığı'nın görev sorumluluk alanı oldukça geniştir. Başkanlık hem idari teşkilat yapısının ahenkli bir şekilde çalışmasından, hem de terör ile ilgili konularda ilgili birimlerin koordineli bir şekilde çalışmasından sorumludur. Bunun yanında Cumhurbaşkanlığı'nın kamuoyu için yapmış olduğu eylem ve faaliyetlerin ne ölçüde halka tesir ettiğini takip etmektedir. 83 milyon nüfusu olan $783.562 \mathrm{~km}^{2}$ yönetsel alana sahip Türkiye'de bu görevleri üstlenmek önemli insan kaynağını gerektirmektedir. Bu geniş yetki alanının etkin bir şekilde yönetebilmek için İdari İşler Başkanı'nın çok sayıda yardımcıya ihtiyacı vardır. $\mathrm{Bu}$ nedenle İdari İşler Başkanı yardımcılığı kadrosunun kurulması gereklidir. Başkanlığın özellikle personel konusunda sıkıntı çekmemesi gereklidir.

- İdari İşler Başkanı, Türkiye Cumhuriyeti Devleti idari teşkilat yapısının en yüksek dereceli memurudur. $\mathrm{Bu}$ durum, ister istemez merkezi yönetimi bünyesine alan devlet kamu tüzel kişiliği içindeki hiyerarşide, İdari İşler Başkanı’na önemli bir “hiyerarşik amir” unvanı kazandırmaktadır.

- İdari İşler Başkanlığının bir diğer önemli görevi, yürütme ile yasama arasındaki köprüyü kurmasıdır. Cumhurbaşkanlığı hükümet sisteminde, Cumhurbaşkanlığı'nın TBMM ile olan ilişkisinde aracı birim İdari İşler Başkanlığıdır. Bu durum, birimin önemini daha da artırmaktadır. Çünkü Cumhurbaşkanlığı Hükümet Sistemi'nin etkin bir şekilde çalışabilmesi için, Cumhurbaşkanlığı'nın parlamento ile ahenk içinde çalışması gerekmektedir. Zira Cumhurbaşkanlığı Hükümet Sistemi'nde Cumhurbaşkanı artık bir partiye mensuptur. Hem bir siyasi partinin lideri hem de yürütmenin başı olarak Cumhurbaşkanı'nın TBMM ile olan ilişkisi, sistemin sorunsuz işleyebilmesi için büyük önem arz etmektedir.

- İdari İşler Başkanlığının bir alt birimi olan Hukuk ve Mevzuat Genel Müdürlüğü, üstlendiği görevler bakımından oldukça dikkat çekicidir. Burada bir noktaya değinmekte fayda vardır. İdari İşler Başkanlığının alt birimleri yeterince bilinmemektedir. Yapılan literatür taramasında özellikle bu alt 
birimlere hiç değinilmediği tespit edilmiştir. Hâlbuki bu alt birimler, İdari İşler Başkanlığının sahip olduğu görev ve yetkilerin büyük bir bölümünü icra etmektedir. Hukuk ve Mevzuat Genel Müdürlüğü, Cumhurbaşkanlığının mevzuatla ilgili bütün görevlerinin incelenip hazırlandığı birimdir. Örneğin, Cumhurbaşkanının kanunları şekil ve esas bakımından Anayasa ve hukukun genel ilkelerine uygunluğunu inceleme görevi bu alt birim tarafından yapılmaktadır. Yine aynı şekilde, Anayasa değişikliğine ilişkin kanunların, Cumhurbaşkanınca halkoyuna sunulması sürecinde, gerekli hukuki incelemeleri bu birim yapmaktadır. Kanun ve Cumhurbaşkanlığı Kararnameleri’nin yayımlanması sürecinde ilgili mevzuatın incelenmesi ve hazırlanması, milletlerarası anlaşmaların içeriğinin incelenmesi, Resmi Gazete'nin yayımlanması, Cumhurbaşkanlığınca çıkarılacak yönetmeliklerin hazırlanması gibi iş ve işlemler Hukuk ve Mevzuat Genel Müdürlüğü tarafından yapılmaktadır. Yani kısaca, Cumhurbaşkanlığının hukuki konuları ile ilgili bütün süreçler bu birim tarafından yapılmaktadır. Son olarak bu birimin bir önemli görevi daha bulunmaktadır. Cumhurbaşkanı çeşitli nedenlerle (sakatlık, sürekli hastalık, kocama vb.) hükümlülerin cezalarını azaltabilmekte, kaldırabilmektedir. Bu durumda ilgili hükümlünün durumu ile ilgili araştırma yapma ve ilgili bakanlığa rapor sunmakla yükümlü birim Hukuk ve Mevzuat Genel Müdürlüğüdür.

- İdari İşler Başkanlığının bir diğer önemli alt birimi Personel ve Prensipler Genel Müdürlüğüdür. Bu birimin önemi, 21 Nisan 2021 tarihinde yayımlanan Cumhurbaşkanlığ Kararnamesi ile daha da artmıştır. Çünkü bu kararname ile Devlet Personel Başkanlığı lağvedilmiş ve görevleri bu birime geçmiştir. Bu birimin en temel görevi, Türkiye Cumhuriyeti idari teşkilat yapısının düzenli ve ahenkli çalışması için gerekli işlemleri yapmaktır. Bunun yanında bakanlar, Cumhurbaşkanı yardımcıları, üst düzey kamu yöneticilerinin atama ve seçme işlemlerini bu birim yapıp Cumhurbaşkanına sunmaktadır. TBMM üyelerinin dokunulmazlığının kaldırılmasına ait işlemler, Cumhurbaşkanına vekâlet işlemleri de bu birimce yapılmaktadır. 21 Nisan 2021 değişikliği sonrası artık; memur ve diğer kamu görevlilerinin tabi olacakları personel rejimlerinin temel ilke ve esaslar bu birimce yapılmaktadır. Kısaca artık kamu personeline ilişkin bütün işlemler (istihdam planlaması, personel alımı, kamu personelinin eğitimi, görev tanımlar1) bu birimce yapılacaktır.

- İdari İşler Başkanlığının bir diğer önemli alt birimi Güvenlik İşleri Genel Müdürlügüdür. Bu birimin stratejik önemi ise devletin güvenlik strateji ve politikalarının hazırlandığı, belirlendiği, geliştirildiği ve uygulandığı birim olmasıdır. Bu birim ayrıca olağanüstü hâl ilan edilen bölgelerde yapılacak faaliyetlerin ve koordinasyonun sağlanması için bir merkez görevi görmektedir.

Sonuç olarak, yukarıda da belirtildiği gibi Cumhurbaşkanlığının can ve mal güvenliğinden kamu personelini ilgilendiren bütün işlemlere, Cumhurbaşkanlığının görev alanına giren bütün mevzuat işlemlerinden devletin güvenliğinin genel koordinasyonuna kadar bütün işlemlerden sorumlu birim İdari İşler Başkanlığıdır. Çalışma sürecinde yapılan incelemelerde İdari İşler Başkanlığının bu kadar önemli görevleri üstlenmesinin bazı sorunları beraberinde getireceği düşünülmüştür.

Bu kadar önemli ve stratejik görevlerin bir birimde olması, iş ve işlemlerin yürütülmesinde gecikmelere neden olabileceği çalışmanın yazarınca düşünülmüştür. Bu nedenle İdari İşler Başkanlığının çalışma durumu, yüklendiği görevlerin ne kadar zamanda yerine getirildiği vb. bilgilerin bir "iş analizi" yoluyla araştırılması gerektiği düşülmektedir. Yapılan iş analizi sonucunda İdari işler Başkanlığının daha etkin ve verimli çalışabilmesi için organizasyonel anlamda neler yapılabileceği tartışılabilir. Fakat şu bir gerçek ki bu kadar önemli ve stratejik görevlerin sadece bir birimde toplanması, bazı sorunların ortaya çıkmasını kaçınılmaz hale getirecektir. Yine çalışma sürecinde yapılan incelemlerde Cumhurbaşkanlığı hükümet sistemine geçişle birlikte ortaya çıkan yeni kurumların ve idari teşkilat yapısının Cumhurbaşkanlığı'nın resmi web sitesine (www.tccb.gov.tr) yer almadığı görülmüştür. Bu durum önemli bir eksiklik olarak görülmüştür. Yeni sistemin anlaşılması için kamu kurumlarının resmi web sitelerine, yapılan değişikliklerle ilgili bilgiler açık ve net şekilde işlenmelidir. 


\section{KAYNAKÇA}

1 nolu Cumhurbaşkanlığı Teşkilatı Hakkında Cumhurbaşkanlığı Kararnamesi (10.07.2018 tarih ve 30474 say1lı Resmî Gazete).

AKINCI, Berat (2017), "Hükümet Sistemleri ve Ülkemizde Olası Hükümet Sistemi Değişikliğinin Etkileri”, Journal of Social And Humanities Sciences Research, S.4(1), ss.1-21.

AKYILMAZ, Bahtiyar (1995), “Tarihi Gelişim İçinde ve Özellikle Montesquieu'de Kuvvetler Ayrıliğı”, Selçuk Üniversitesi Hukuk Fakültesi Dergisi, S.(Prof. Dr. Halil Cin'e Selçuk Üniversitesinde 10. Hizmet Yı1ı Armağanı Özel Sayıs1), ss.43-60.

BURHAN, Hasan (2020), "Siyasal Rejimler: Meclis Hükümeti ve Parlamenter Sistem Uygulamaları”, Çağdaş Siyasal Sistemler Türleri ve Belli Başlı Uygulamaları (Ed. Hasan Burhan, Mustafa Karaman, Mehmet Durgut), Nobel Yayınevi, Ankara, ss.111-116.

CANER, Zehra (2013), "Parlamenter Sistem ile Başkanlık Sisteminin Analizi ve Başkanlık Sisteminin Türkiye'de Uygulanabilirliği”, Selçuk Üniversitesi Hukuk Fakültesi Dergisi, S.21(1), ss.183-206.

ÇAM, Esat (1995), Siyaset Bilimine Giriş, Der Yayınları, İstanbul, 9. Baskı.

ÇEKİÇ, Mustafa (2016), “1982 Anayasası'nın Hükümet Sistemi Açısından Değerlendirilmesi”, Uyuşmazlık Mahkemesi Dergisi, S.7, ss.441-478.

DEMIR, Fevzi (2000), “Cumhuriyet Dönemi Türk Anayasaları ve Hükümet Sistemleri”, Prof. Dr. Seyfullah EDís'e Armağan (Ed. Zafer Gören), Dokuz Eylül Üniversitesi Yayınları, İzmir, ss.59-78.

DIŞ IŞLERİ BAKANLIĞI (2021), "Unvanlar-Büyükelçi”, Dıș İşleri Bakanlığı Kurumsal Web Sayfası, https://www.mfa.gov.tr/unvanlar.tr.mfa, (Erişim Tarihi: 15.06.2021).

ERGIL, Doğu (2015), “Başkanlık Sistemi ve Türkiye”, Başkanlık Sistemi (Ed. Murat Aktaş, Bayram Coşkun), Liberte Yayınlar1, Ankara, ss.21-47.

ERTAŞ, Türker (2018), Kuvvetler Ayrılığı ilkesi Bağlamında: Yasama, Yürütme ve Yargı Organları Arasındaki Modern İlişkiler, Seçkin Yayınevi, Ankara.

GÖZLER, Kemal (1999), "Hukuk Açısından Monarşi ve Cumhuriyet Kavramlarının Tanımı Sorunu”, Ankara Üniversitesi SBF Dergisi, S.54(1), ss.51-62.

GÖZLER, Kemal (2020), Anayasa Hukukunun Genel Teorisi, Ekin Yayınevi, Bursa, Cilt.1.

HEKİMOĞLU, Mehmet Merdan (2009), Anayasa Hukukunda Karşılaştırmalı Demokratik Hükümet Sistemleri ve Türkiye, Detay Yayınları, Ankara.

KARAMAN, Mustafa (2020), Demokratik Siyasal Sistemde Parlamenter Denetim ve Türkiye Uygulaması, Onikilevha Yayınları, Ankara.

KESKINSOY, Ömer ve KAYA, Semih Batur (2018), “Türkiye'nin Hükümet Sistemleri Üzerine Bir Değerlendirme”, Türkiye Barolar Birliği Dergisi, S.137, ss.67-96.

KILINÇ, Doğan (2016), “Türkiye'de Bitmeyen Tartışma: Hükümet Sistemi Üzerine Değerlendirmeler”, Ankara Hacı Bayram Veli Üniversitesi Hukuk Fakültesi Dergisi, S.20(1), ss.447-510.

KIŞLALI, Ahmet Taner (1995), Siyasal Sistemler, İmge Yayınevi, Ankara.

KORKMAZ, Tuğrul (2016), “Türkiye Eksenli Bir Hükümet Sistemi Analizi”, Akademik Hassasiyetler, S.3(6), ss.43-57.

MILliYET GAZETESİ (2021), “Anayasa’nın 134 Hükmü Değiştirildi”, Milliyet Gazetesi, https://www.milliyet.com.tr/siyaset/anayasanin-134-hukmu-degistirildi-6426456 (Erişim Tarihi: 18.05.2021).

MUMCU, Ahmet (1986), “1924 Anayasası”, Atatürk Araştırma Merkezi Dergisi, S.2(5), ss.383-399.

ÖZDEMİ, Hakan (2018), 100 Soruda Hükümet Sistemleri, Birleşik Krallık, Almanya, ABD, Fransa, İsveç, Türkiye, Seçkin Yayıncılık, Ankara. 
SEZGINER, Murat (2010), Günümüz Demokrasilerinde Kuvvetler İlişiklisi ve 1982 Anayasasında Sorunlar, Seçkin Yayınevi, Ankara.

SUBASSI, Münevver ve OKUMUŞ, Kübra (2017), “Bir Araştırma Yöntemi Olarak Durum Çalışması”, Atatürk Üniversitesi Sosyal Bilimler Enstitüsü Dergisi, S.21(2), ss.419-426.

TUNÇ, Bilal (2020), “Türk Anayasa Tarihinde 1961 Anayasası'nın Yeri ve Önemi”, Karadeniz Araştırmaları Dergisi, S.17(67), ss.657-692.

TUNÇAY, Mete (1969), Batıda Siyasal Düşünceler Tarihi: Yeni Çă̆, Seçilmiş Yazılar, Ankara Üniversitesi SBF Yayınları, Ankara.

YAVUZ, Bülent (2008), “2007 Anayasa Değişikliğinin Doğurduğu Tereddütler ve Çözüm Yolları”, Ankara Hacı Bayram Veli Üniversitesi Hukuk Fakültesi Dergisi, S.12(1), ss.1173-1214.

YAYLA, Atilla (2014), Karşılaştırmalı Siyasal Sistemler, Adres Yayınları, Ankara, 3. Baskı.

YILDIRIM, Ali ve ŞİMŞEK, Hasan (2006), Sosyal Bilimlerde Nitel Araştırma Yöntemleri, Seçkin Yayınları, Ankara.

YSK - YÜKSEK SEÇiM KURULU (2017), "16 Nisan 2017 Anayasa Değişikliği Halkoylaması”, YSK Kurumsal Web Sayfası, https://www.ysk.gov.tr/doc/dosyalar/docs/2017Referandum/2017HOOrnek134.pdf (Erişim Tarihi: 08.09.2020).

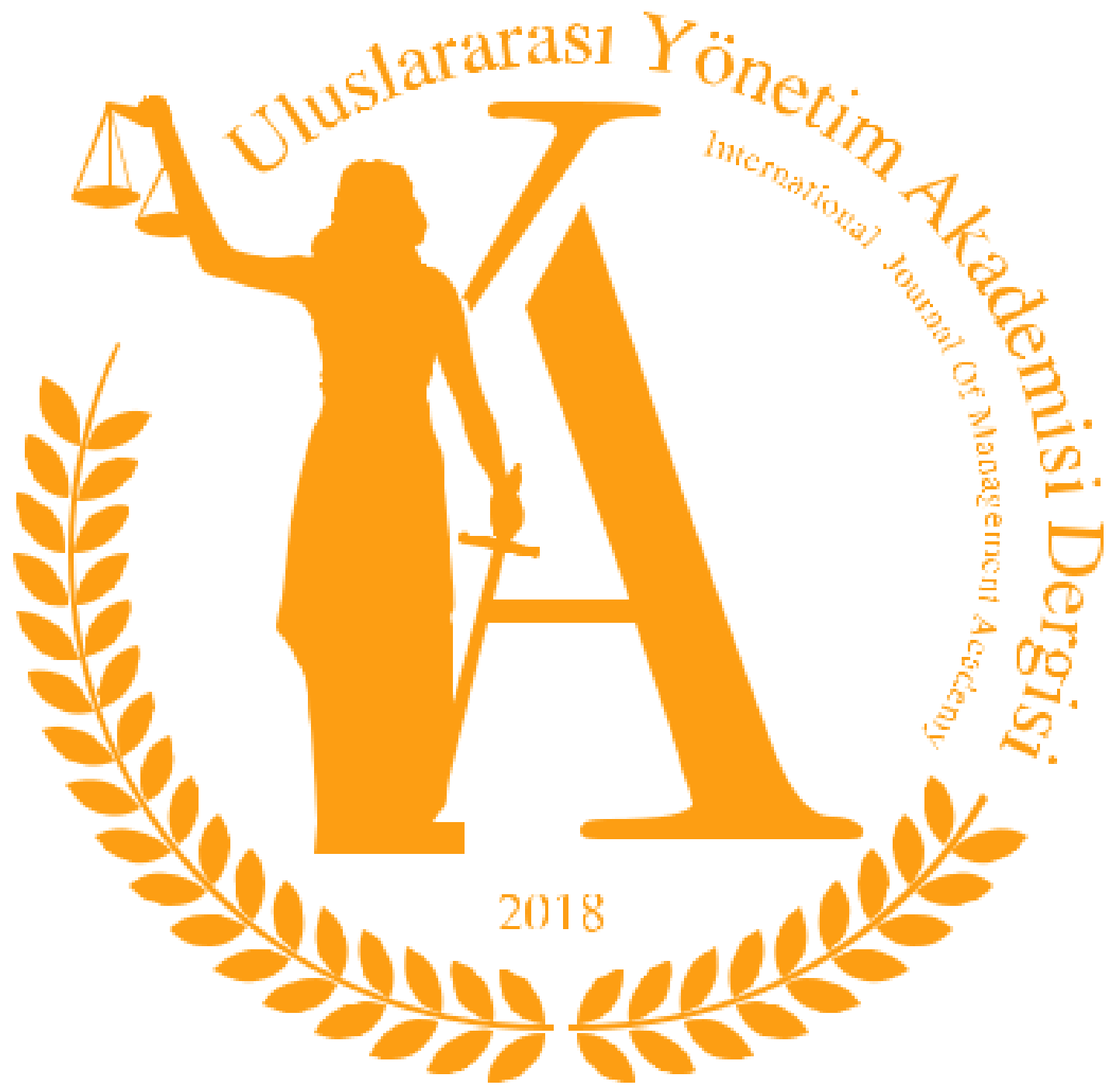

